\title{
Concept Map Assessment: An Experimental Mathematical Study
}

\begin{abstract}
In this experimental study, we analyzed the ability to understand and ability to share mathematical knowledge of our modified context maps (MCM) and compared them to the standard linear form of examination. For these purposes, the categorization of mathematical knowledge to local and structural understanding and craft was defined. Experimentation was conducted during the regular final oral exam of Linear algebra courses for computer science freshmen university students. No benefits were given for participation in the experiment.

According to the questionnaire self-report student data, the MCM method combined with student-examiner discussion shares statistically significantly better structural understanding than the linear form. However, the MCM method shares less local understanding than the linear form, given randomized data set. Moreover, students claim that the MCM oral examination form is almost as objective as other oral exams they attempted during faculty study. Students created surprisingly good modified cognitive maps, although we assumed their low to none practical experience with concept mapping.
\end{abstract}

Keywords: concept map, assessment, mathematics assessment, linear algebra, structural understanding

Authors:

Mgr. Jiř́ Šejnoha, Department of Applied Mathematics/Department of Software and Computer Science Education, Faculty of Mathematics and Physics, Charles University, email: jiri.sejnoha@mff.cuni.cz

RNDr. Pavel Klavík, Ph.D. ${ }^{1}$, OrgPad, www.orgpad.com, email: klavik@orgpad.com

\footnotetext{
${ }^{1}$ OrgPad (www.orgpad.com) is an online platform for creating and sharing modified concept maps.
} 


\section{Introduction}

Changing the environment brings new challenges. Reacting to them urges them to orient in new situations, understand them, and understand their concepts and structure instead of rote memorization of procedural techniques or facts.

The elemental learning question is how to create, evolve, teach, share, and evaluate these concepts and their inner structure? And how to support these processes?

This study describes an application of the concept mapping assessment (CMA) based on modified concept maps (MCM) to provide an insight into learners' personal understanding and organization of knowledge, simultaneously to test the ability to share "how student structures his or her understanding of a concept or group of concepts." (Daugherty, Jenny L.; Custer, Rodney L.; Dixon, Raymond A. (2012), p. 11)

For this purpose, we define the division of mathematical knowledge into components of local and structural understanding and craft and map them onto structure MCM.

\subsection{Concept maps}

Novak, Joseph D., Cañas. Alberto J., in the text The Theory Underlying Concept Maps and How to Construct and Use Them defines concept maps as "...graphical tools for organizing and representing knowledge. They include concepts, usually enclosed in circles or boxes of some type, and relationships between concepts indicated by a connecting line linking two concepts. Words on the line referred to as linking words or phrases, specify the relationship between the two concepts. ..." (Novak, Joseph D., Cañas. Alberto J. (2008), p. 1) see example Figure 1 (Novak, Joseph D., Cañas. Alberto J. (2008). 


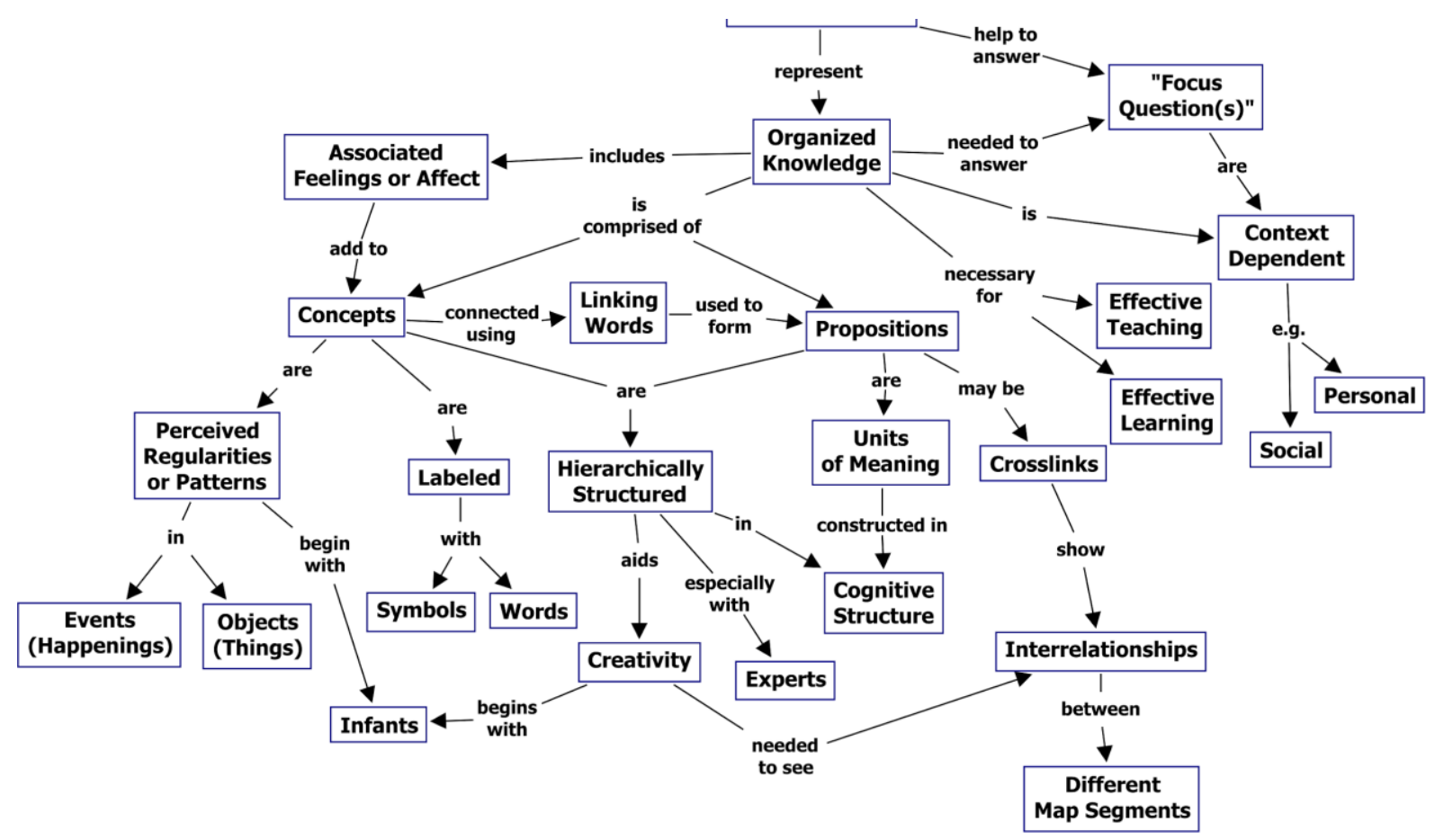

Ruiz-Primo, M. A. and Shavelson, R. J. (1996), p. 570, construe the concept map as "... a graph consisting of nodes representing concepts and labeled lines denoting the relation between a pair of nodes."

Theoretical learning background of the concept map (Novak, Joseph D., Cañas. Alberto J. (2008) found in Ausubel's assimilation theory.

Ausubel's argued that "... people think and learn assimilation of new concept and proposition into existing concepts what he called a cognitive structure, that construes as individual's existing organization, stability, and clarity of knowledge in a particular subject matter field at any given time." (Ausubel, 1963, p. 217).

Novak and Gowin (1984) p. 40, claim "Concept mapping is such an educational tool; it has been developed specifically to tap into a learner's cognitive structure and to externalize, for both the learner and the teacher, to see, what the learner already knows.". The concept maps are a visual tool for operationalizing Ausubel's theory, respectively.

According to Ruiz-Primo, M. A. and Shavelson, R. J. (1996), p. 570, "a concept map is a structural representation consisting of nodes and labeled lines. The nodes correspond to important terms (standing for concepts) in the domain. The lines denote a relation between a pair of concepts (nodes). And the label on the line tells how the two concepts are related. The combination of two nodes and a labeled line is called a proposition. A proposition is a basic unit of meaning in a concept map and the smallest unit that can be used to judge the validity of the relation (line) drawn between two concepts (e.g., Dochy, 1994)." Besides, they declare that "Concept maps thus purport to represent some important aspects of student's declarative knowledge in a content domain." 
Novak and Cañas define the concept as a perceived regularity in events or objects, or records of events or objects, designated by a label. (Novak, Joseph D., Cañas. Alberto J. (2008)

Deese's (1968) associationist memory theory describes an alternative approach of concept maps, where concepts are represented as nodes in a network and the nodes are linked by the associative overlap of two concepts with unlabeled lines. The associationist theory founded the ground for concept map approaches represented by associations or similarity and without hierarchical fashion.

Novak and Govin (1984) and Novak (1998) propose the following applications of concept maps: a) as learning strategies in which learners create concept maps during learning, b) as adjuncts to learning by providing teacher-generated concept maps with lessons, c) as evaluation tools in which drawing a concept map is a way to evaluate what students know.

Further, Novak, J., Gowin, D., \& Kahle, J. (1984) state that concept mapping can improve education: a) as a learning strategy for, e.g., math (Vagliardo, J. J., 2004), economy statistics (Chei-Chang Chiou, (2009), physics (Yuruk, N., Beeth, M.E. \& Andersen, C. Res Sci Educ (2009), b) as a strategy for planning curriculum, e.g. (Riesco, M., Fondon, M. D., \& Alvarez, D. (2008) c) as an instructional strategy (Stoddart, T. (2006) d) as an assessment of, e.g., medicine (West, D. C., Park, J. K., Pomeroy, J. R. and Sandoval, J., 2002).

Daugherty, Jenny L.; Custer, Rodney L.; Dixon, Raymond A. (2012) assert three cognitive processes are activated by mapping, see Table 1 .

Table 1: Cognitive processes are activated by mapping, Daugherty, Jenny L.; Custer, Rodney L.; Dixon, Raymond A. (2012)

\begin{tabular}{ll}
\hline Cognitive process & How mapping primes the process \\
\hline Selecting & Learners focus on or choose which concept to use as nodes \\
Organizing & Learners physically arrange the nodes to show the relationship among them \\
& $\begin{array}{l}\text { Learners translate from one mode of representation into another, such as from } \\
\text { linear words, which requires connecting incoming information with prose } \\
\text { structures stored in long-term memory, such as compare-and-contrast }\end{array}$
\end{tabular}

In this study, we focus on the assessment or evaluate the usage of concept maps.

\subsection{Modified Concept Maps}

We derive Modified Concept Maps (MCM) from the concept map as associationist, no hierarchical cognitive map, consisting of two components: concepts and multilink relations.

A concept is defined as a perceived regularity in events or objects designated (Novak, Joseph D., Cañas. Alberto J. (2008). With our specification, the concept is written and could be sentences, images, symbols, formulas, etc., and their combination. 
A relation is labeled or unlabeled, oriented, or not oriented multilink connection between two concepts.

See students MCM depiction example Figure 6: Student example MCM form preparation Figure 6: Student example MCM form preparation Figure 6.

Though various concept map implementations Schroeder, N.L., Nesbit, J.C., Anguiano, C.J. et al. (2018), Table 2 characterizes differences between elemental types of concept maps according to Novak, Joseph D., Cañas. Alberto J. (2008) and MCM.

Table 2: Characterization MCM and elemental types of concept maps

\begin{tabular}{llll}
\hline $\begin{array}{l}\text { Type of concept } \\
\text { map }\end{array}$ & Cognitive Map & Network Concept Maps & Modified Concept Maps \\
\hline Author & $\begin{array}{l}\text { Novak, Joseph D., } \\
\text { Cañas. Alberto J. } \\
(2008)\end{array}$ & $\begin{array}{l}\text { Associationist theory } \\
\text { Deese, (1965) }\end{array}$ & this study \\
Entities & Concepts & Nodes & Concepts \\
$\begin{array}{l}\text { Representation of } \\
\text { entities }\end{array}$ & Word, symbol & Word, symbols & $\begin{array}{l}\text { Text symbols, formulas, etc. and } \\
\text { their combination }\end{array}$ \\
Relations & Line & Lines & Line/Multilink \\
Types of relations & Labeled by word & Unlabeled by word & Labeled or unlabeled \\
Hierarchality & Hierarchical fashion & $\begin{array}{l}\text { Not have to be } \\
\text { hierarchical }\end{array}$ & Not have to be hierarchical
\end{tabular}

\subsubsection{Graphical representation}

Analogically to the mathematical term of the graph, where it is distinguished between graph as a structure represented by a pair $\mathrm{G}=(\mathrm{V}, \mathrm{E})$, where $\mathrm{V}$ is a set of vertices and $\mathrm{E}$ is a set of edges (links or lines)), and graph as its depiction. The concept maps term can be distinguished into a concept map as a structure and its depiction. Moreover, one graph can have more realizations of its depiction with different properties. Different depictions of a concept map can have different properties and express different types of personal understanding and organization of map and respective knowledge. 


\subsection{Concept Maps assessment tools}

The application of concept maps in the educational process is increasingly more popular. The usage of concept maps as an assessment tool is not so frequent, which creates a research gap.

The research contribution is to:

a) prove contribution and extend evidence of concept mapping assessment on general assessment field implemented on mathematical field

b) prove MCM's ability to share and test how a student structures and has structured personal concepts to understand a given mathematical subject to the standard linear form of examination.

The concept maps assessment tool is a procedure measuring declarative knowledge. Ruiz-Primo, M. A. and Shavelson, R. J. (1996), p. 573 distinguish "assessment as a combination of a task, a response format, and scoring system." Ruiz-Primo, Maria \& Schultz, Susan \& Shavelson, Richard. (2001), p. 261, claim there is "... reliability and validity evidence on effects of two mapping techniques, "fill in the map" and "construct-a-map" in the student's organization of the declarative knowledge in a given domain. Ruiz-Primo, M. A. and Shavelson, R. J. (1996) also conclude three-way concept map tasks: a) task on-demand (construct a concept map; fill in skeleton map) b) task on constrains (refers to constrains of map what student should or shouldn't do, e.g., count of connection, explain concepts in a map,) c) task content structures (refers to the intersection of the task demands and constraints with the structure of the subject domain to be mapped cited).

\subsubsection{CMC and Bloom's taxonomy}

In terms of Revisited Bloom's taxonomy (Yuruk, N., Beeth, M.E. \& Andersen, C. Res Sci Educ (2009) and in this study implementation the MCM test method all segments of the Bloom's hierarchy: remember in writing facts, e.g., equations or statements, understand in explanation of statements or in statement's proof, apply section in solving example or use general statement case to a concrete situation, analyze part in organization facts, e.g., implication theorems or distinguishing validity of statements, evaluation in argumentation assumption in statements and creation in depicting personal structural understanding compared with lessons.

\subsection{Scoring}

The fundamental question is how to transform students' concept maps into objective, reliable and valid scores. Many scoring techniques have been proposed.

E.g. Anohina-Naumeca, Alla \& Grundspenkis, Janis. (2009) classify five scoring criteria: a) type of scoring: quantitative, qualitative or combination, b) scoring method: structural, relational or combination, c) scoring based on an expert map or without its usage, d) scheme offered or used for automatic or human-based scoring, and e) presence or lack of 
restrictions concerning the application of a scheme. And compare 16 scoring schemes of the concept maps.

West, D. C., Park, J. K., Pomeroy, J. R. and Sandoval, J. (2002), p. 820 and RuizPrimo, M. A. and Shavelson, R. J. (1996), p. 594, declare a limitation and uncertainty of the validation of the concept maps.: "The validity of concept mapping assessment is largely dependent on how the maps are interpreted and/or scored ... enormous variation in conceptmapping techniques produces different representations and scores."

Alternatively, Novak, J., \& Gowin, B. (1984), p. 105 describe limits of the scoring methods of the concept maps: "Any scoring key for concept maps has a certain degree of subjectivity inherent in it, as in fact is the case with all evaluation instruments. True-false and multiple-choice tests may score "objectively," but the choice of topics and the wording of questions are subjective and, to some extent, arbitrary."

We conclude that accurate reliability, validity, and exclusion of a concept map's subjectivity scoring is challenging and needs more future research.

\subsubsection{Structural, local understanding and craft}

In this section, we declare the classification of mathematical knowledge into three parts and map these parts onto components of cognitive maps.

In this study, the notion of sharing of understanding (further referred to as just sharing) contains various processes of examination: student cognitive processes (topic understanding, ability to transform personal understanding to MCM or linear form and ability to create and modify a map or linear form, discussion, etc.), examiner cognitive processes (topic understanding, ability to understand MCM or linear form, scoring method, etc.) and discussion.

We define the classification of the personal mathematical knowledge of a given topic to:

a) Local understanding - knowledge of facts: definitions, theorems, proofs, description of algorithms, when possible, graphical visualization or example, practical usage, notices, etc.

b) Structural understanding - knowledge of relations between local understanding facts: implication, equivalation, be an assumption, be a consequence, be the usage of, be an example of, etc.

c) Craft-

- Local craft - procedural ability to compute/enumerate, do it with ingenuity, shrewdness, and agility, with the usage of correct a clear procedural knowledge (e.g., integral substitution, Gauss elimination) - shortly operationalize local understanding

- Structural craft - procedural ability to create, modify, share and cooperate structural understanding - shortly operationalize structural understanding 
The local and structural understanding describe states, whereas the craft describes processes and the ability to do these processes and their performance.

Given by Revisited Bloom's taxonomy Anderson, Lorin W.; Krathwohl, David R., eds. (2001) and its classification "Major types and subtypes of the knowledge dimension": the Local understanding represents factual and conceptual knowledge, the Structural understanding means metacognitive knowledge, the Local craft cover procedural knowledge, and the Structural craft use procedural knowledge to metacognitive knowledge.

Table 3: Describes the mapping of the classification of the mathematical knowledge onto cognitive map components.

Table 3: Mapping classification of the mathematical knowledge onto cognitive map components

\begin{tabular}{lll}
\hline $\begin{array}{l}\text { Division of personal } \\
\text { knowledge of the given } \\
\text { topic }\end{array}$ & Mapping & Concept map component \\
\hline $\begin{array}{l}\text { Local understanding } \\
\text { Structural understanding }\end{array}$ & $\begin{array}{l}\text { Is mapped onto } \\
\text { Is mapped onto }\end{array}$ & $\begin{array}{l}\text { Concepts } \\
\text { Links/propositions } \\
\text { Processes with the } \\
\text { components of the concept } \\
\text { Craft }\end{array}$ \\
$\begin{array}{l}\text { Processes with the } \\
\text { components of the } \\
\text { concept map }\end{array}$ & $\begin{array}{l}\text { (enumeration) } \\
\end{array}$
\end{tabular}

\subsection{Research question and hypothesis}

We have designed a method using the modified concept map to support the sharing of structural and local understanding throughout the assessment and to test whether the modified concept map shares structural understanding better than the standard linear form of evaluation, simultaneously without loss of sharing of local understanding.

To compare these two forms, we use empirically collected data from questionnaires self-report filled by university freshman students.

Examiners observe students' ability to operationalize their personal understanding of a topic by MCM or linear form and, for both, by the following oral examiner-student discussion.

To control the oral part of the examination experiment, students compare their perception of objectivity of the oral part of the examination to other oral subject examinations they had attempted.

\subsubsection{Hypothesis}

Based on research questions and student questionnaires self-report, we hypothesize:

Hypothesis 1 (H1): MCM shares structural understanding better than linear form.

Hypothesis 2 (H2): MCM shares local details at least as well as linear form. 
Support Hypothesis 1 (SH1): oral part of the examination using MCM is at least as objective as other forms of an oral exam at the university they attempt.

Support Hypothesis 2 (SH2): MCM examines structural understanding better than other forms of exam students had attended. 


\section{Method}

\subsection{Participants, placement and runs}

Undergraduate full-time freshman students of the Computer Science study branch at the Faculty of Mathematics and Physics (MFF UK), Charles University (Czech Republic, EU) participated in this study. The study was performed in the final examination of the obligatory course of Linear algebra I and Linear algebra II; consequently, students were highly motivated to succeed in the exam. No reward (credits, etc.), extras, fees, or other benefits were provided to students for study participation. Students provided informed consent. More than $75 \%$ of participants were a man in gender view.

The study was conducted from 2015 to 2017 in three academic years consisting of preparation/experimental trial runs and regular runs - see Table 4.

Table 4: Study experiments stages flow

\begin{tabular}{|c|c|c|c|c|c|}
\hline Season & Spring 2015 & Fall 2015 & Spring 2016 & Fall 2016 & Spring 2017 \\
\hline $\begin{array}{l}\text { Phase of the } \\
\text { experiment }\end{array}$ & Proof of concept & Trial experiment & Trial experiment & $\begin{array}{r}\text { Regular } \\
\text { experiment }\end{array}$ & $\begin{array}{r}\text { Regular } \\
\text { experiment }\end{array}$ \\
\hline $\begin{array}{l}\text { Course } \\
\text { (name and university } \\
\text { subject id code) }\end{array}$ & $\begin{array}{r}\text { Linear algebra II } \\
\text { NMAI058 }\end{array}$ & $\begin{array}{r}\text { Linear algebra I } \\
\text { NMAI057 }\end{array}$ & $\begin{array}{r}\text { Linear algebra II } \\
\text { NMAI058 }\end{array}$ & $\begin{array}{r}\text { Linear algebra I } \\
\text { NMAI057 }\end{array}$ & $\begin{array}{r}\text { Linear algebra II } \\
\text { NMAI058 }\end{array}$ \\
\hline Count of exam dates & 4 & 6 & 7 & 14 & 13 \\
\hline Count of examinations & 34 & 42 & 66 & 113 & 113 \\
\hline $\begin{array}{l}\text { Count of structural } \\
\text { diagrams form }\end{array}$ & - & - & 48 & 62 & 54 \\
\hline Count of linear forms & - & - & 18 & 51 & 59 \\
\hline Count of students & - & - & - & 89 & 85 \\
\hline $\begin{array}{l}\text { Randomness of form } \\
\text { selection }\end{array}$ & Students choice & Students choice & Students choice & Random & $\begin{array}{r}\text { Random } \\
\text { (student could } \\
\text { change form in } \\
\text { case disapproval } \\
\text { of choice) }\end{array}$ \\
\hline
\end{tabular}

This experimental research was initiated in the examination of Linear algebra II in Spring 2015 as proof of the concept of using the MCM form to partially examine structural understanding in Linear algebra. Students were also asked to fill questionnaires consisting of several open questions asking about the method and the overall impression of the exam.

In Fall 2015 and Spring 2016, the proof of concept stage was followed by a trial experiment in Linear algebra I and II. Further, open questions were added to the questionnaire in Fall 2015, and the final version of the questionnaire was introduced and tested already in Spring 2016.

Since Linear algebra is one of the main subjects, education is divided into two parallel tracks with different lecturers. In Fall 2016 and Spring 2017, the regular experiment was conducted in both tracks, so it covered all the freshmen undergraduate students enrolled in computer science at Charles University in the school year 2016. 
In Fall 2016 and Spring 2017, the assignment of oral part form was randomized because of the elimination of student biases (form preferences, prior preparation, etc.).

For hypothesis verification are used data from Fall 2016 and Spring 2017 only.

\subsection{Experimental design}

\subsubsection{Form}

To prove the contribution of MCM form sharing structural and local understanding was chosen an experimental comparison of the linear and structural form given by student's questionnaires self-reports. Student's opinion was acquired without knowledge of their previous results (written and oral part) to avoid biases in their answers.

Prior knowledge of student structure understanding or knowledge organization was limited on expert teaching experience, and estimation, supported by proof of concept and trial runs.

\subsubsection{Regulation limitation of the study}

The study was conducted during regular subject final exam regulated by "Study and examination regulations" at Charles University and "Higher Education Act of Czech Republic" (following term regulation). Therefore, the examination run must correspond to the course curriculum and be comparable with standard math examination involving local understanding and craft. The collection of all experimental data was voluntary, and the students were given informed consent.

\subsubsection{Description of standardized Linear algebra experiment examination}

The experiment hypothesis was tested in the process of Linear algebra I and II final examination. Students have 3 independent examination attempts to pass the course given by Regulation.

All exam runs follow an equal composition, consisting of the written/test part and the oral part.

The written part was a standard test in Linear algebra testing precise knowledge from lectures and composed of: mathematical definition, theorem with proof, numerical and theoretical problems scored by point ranking.

The oral part is composed of the preparation phase, where students prepare their own understanding and facts on randomly assigned topic and form, and the discussion with examiners using students' written preparation.

The assigned preparation part form was one of two forms of sharing of understanding the topic of the oral exam:

a) Linear form - a linear sequence of definitions, theorems, proofs, examples, as in a standard mathematical book (see example Appendix A.b) in a given topic. 
b) MCM form - a modified cognitive map covering the main definitions, ideas, theorems, proofs, and their connections within the given topic and/or important connection outside the topic (see example Appendix A.a).

The oral part doesn't contain procedural numerical tasks by assignment but can be done by the student to demonstrate some idea, algorithm, etc.

\subsubsection{Examiners}

The examiners' team consists of:

a) The lecturer and the guarantor of one track of Linear algebra I and II (Fall 2016 and Spring 2017), Associate Professor and Head of the Optimization Division and the Interval methods Group at the Department of Applied Mathematics MFF UK, and lecturing Linear algebra for several years. He also authored popular lecture notes in Czech.

b) The lecturer and guarantor of the second track, Assistant Professor at the Department of Applied Mathematics, MFF UK.

c) Two Ph.D. students at the Department of Applied Mathematics and Computer Science Institute of Charles University are principal investigators and authors of this paper. Both being teaching assistants of Linear algebra for more than five years.

Since different tracks were used separate exam dates, there were always three examiners: the lecturer of the corresponding track and both Ph.D. students/investigators.

\subsection{Materials and procedure}

\subsubsection{Instruction of construction}

Construction instruction for students of preparation part of the oral part of the examination.

Instructions for preparation part of the oral part of the examination:

1) Case MCM form

Construct an MCM map of the randomly assigned topic of your understanding with a focus on mathematics scope; invited are overlaps to close relations to other topics if exists or your personal understanding; however, it must be reasonable.

Construct nodes mainly of definitions, theorems, and proof, algorithm, when possible graphical visualization or example, practical are usages, notices, etc., matching local understanding.

Edges link, according to your personal understanding, are not prescribed by types, purposes, etc. On the other side, edges could be the implication, equivalation, usage, concrete usage of definition in the theorem, algorithm implementation. Think about which edges are fundamental, which edges are complementary etc., matching to structured understanding. 
Due to time and personal examination limitations, we lead up a student to focus on representation of their understanding by structure and concept/nodes content, rather than graphical and design features.

\section{2) Case Linear form}

On the randomly assigned topic, write your understanding, in linear form, with a focus on mathematics scope, invited are overlaps to close relations to other topics if exists, or your personal understanding however it must be reasonable. Write down mainly definitions, theorems and proof, algorithm, when possible graphical visualization or example, practical are usages, notices, etc. matching to local understanding.

\subsubsection{Procedure of examination runs}

The procedure describes regular runs of study. Due to personal limits on a particular exam date, the examination of all courses was done in multiple exam dates (each for about 5 to 15 students).

All lectures, examinations, materials, and discussions were done in the Czech language.

In the last lecture of each semester, students were presented with a description of the exam and told about the experiment, including examples of previous works and a structural diagram of one of the examiners.

\subsubsection{Procedure of particular exam}

At the beginning of each exam, students got the same instruction about the whole examination course, followed by specific instruction on the written part of the exam.

For each exam date, the written part was done in the morning (taking 60 or 90 minutes in different tracks, respectively).

Written part tests were scored by examiners; each examiner scored a particular problem separately through all tests per exam date - to equalization judgment range for all students. The final test score was evidenced by the lecturer, hidden before the rest of the examiners and students to make written and oral examination part score independent - to avoid biases. The students were not told the results score of the written part until the end of the oral part of the exam.

At the beginning of each oral part of the exam were given specific instruction for the oral part. Each student randomly chooses the form of examination (linear or MCM) and one of the topics:

- 6 topics for Linear algebra I: systems of linear equations; matrices; groups and algebraic fields, vector spaces; bases and linear mappings;

- 4 topics for Linear algebra II: dot products, norms and orthogonality; determinants; eigenvalues; positive definite matrices and quadratic forms. 
Each student got a blank A3 paper with an identification header at the header side and a student questionnaire from the underside - see Appendix A, B examples.

In the case of the spring semester, the student could change the assigned form but was asked not to do it to improve experiment independence. In the case of requested form change, students were assured, there are no scoring (or other) consequences related.

Students began working on preparation drawing MCM or linear by chosen form. When students thought the preparation was ready, asked for discussion with the examiner, who was chosen randomly, Ph.D. students had the limitation to had no exam with students they taught.

The written preparation works as a foundation for discussion. The students were asked to explain their own understanding. Both structural and local understanding parts were asked.

Especially to explain why is crosslink done, what crosslink means, what is its purpose; explain the content of nodes, in case structural diagram form. To explain the content of nodes and asked to describe relations between them in the MCM form.

A student could transform, repair or complete written preparation based on the ongoing discussion. To hold phases of the exam, progress the written parts made by the alone student (blue) and made during the discussion (green) was distinguished by colors of writing (red examiner).

The overall time of oral part spending per student takes approximately. 15-45 min.

When the discussion has done, the teacher asked the student to fill the questionnaire and set the final score of the oral part; both did it separately before knowing the results to avoid influence-filled results.

\subsubsection{Questionnaire}

The questionnaire was voluntary, comparing two forms of oral part and comparing it with other exams at the university (95\% questionnaires were filled), the question on perceiving examination objectivity was involved. Each questionnaire consisted of several open-ended and closed-ended questions. Unless stated otherwise, all closed-ended questions were on the 7-point Likert scale from -3 to +3 with labeled extremal points see example Appendix B.

Table 5: Wording of the students' questionnaire questions describes the questionnaire questions and the corresponding study hypothesis.

Table 5: Wording of the students' questionnaire questions

\begin{tabular}{cl}
\hline Hypothesis & \multicolumn{1}{c}{ Wording of the question } \\
\hline H1 & $\begin{array}{l}\text { Independently on your assigned form, evaluate how much of structured understanding is shared by MCM form. } \\
\text { Independently on your assigned form, evaluate how much of structured understanding is shared by linear form. }\end{array}$ \\
\hline H2 & $\begin{array}{l}\text { Independently on your assigned form, evaluate how much of the local understanding is shared by MCM form. } \\
\text { Independently on your assigned form, evaluate how much of the local understanding is shared by linear form. }\end{array}$ \\
\hline SH1 & Were structural diagrams more or less objective compared to other forms of exams at the faculty? \\
\hline SH2 & Rate if the MCM form evaluates structural understanding better than another oral exam you attempt.
\end{tabular}




\subsubsection{Examination scoring methods}

Both parts, written and oral examination, were rated on a scale from 0 to 100 points.

The final students' score was the mean value of the written and oral part of the examination, with acceptance lower bound on each score separately.

Scoring oral part includes:

a. Local understanding: score contend of each concept - correctness, definitions, theorems, proofs, logical steps, completeness

b. Structural understanding: coverage of the topic, reasonable overlaps to close topics, edges and its explanation (MCM form only), missing connections

c. Students ability to transform written structural and local understanding: add, delete, change explanation, nodes or links (MCM form only); correct or complete of concepts; if students do itself or after hints; students' exactness and logical steps

d. Information shared by speech discussion

The student was asked to write every substantive spoken information on paper.

Although in oral part was used two different methods of student preparation, that are testing on existence and rate supportability/influence to share structural and local understanding, the examiners evolve all part of the topic structural and local parts.

\subsubsection{Examiners judgment calibration}

All examiners teach Linear algebra 1 and Linear algebra 2 at Charles University for multiple years, using identical syllabus and lecture notes. Before exam runs, examination judgment, form, and calibration were discussed to ensure equal requirements from students. Also, several first examinations were observed by other examiners by themselves. In idle time the examiners simultaneously observed examination underway. Examinations experiences were regularly discussed. 


\section{Results}

\subsection{Data restriction}

Because of the elimination of students' form preferences influence, only data with the randomized process of assignment of oral part examination form for hypothesis testing/verification (only fall 2016 and spring 2017 data) were selected.

Selected data were divided by:

a) a different way of oral's preparation part of examination assignment

b) assumed/expected limitation of students' experience with oral linear evaluation form (including other study program courses)

to Data sets, see Table 6 and Table 7.

Because the linear form of oral examination is standard on the faculty, we suppose that students have significant experience with the linear form of examination, including the oral form of examination in the case of spring semester's course Linear algebra II NMAI058, contrary to the assumed lower experience in fall semester's Linear algebra I NMA057. The students should attempt at least 2 different mathematical (Mathematical Analysis and Discrete Mathematics) examinations and at least 3 computer science examinations (Programming, Principles of Computers, Introduction to Networking) in the fall semester and at least the equal count of examinations in the spring semester.

Data set 1 consists of restricted data where we assume students' significant experience with oral examination form, compared to Data set 2, where students may not have to have significant experience with the oral form of examination.

Analogically, according to oral examination form experience, were divided data to data Data set 3 and Data set 4, moreover, Data set 3 and Data set 4 incorporate evidence of MCM form of examination only.

The data set specification is summarized in Table 6 and Table 7. 
Table 6: Data set 1 and Data set 2 specification

\begin{tabular}{|c|c|c|c|c|c|}
\hline Data set & \multicolumn{2}{|r|}{ Data set 1} & \multicolumn{3}{|c|}{ Data set 2} \\
\hline School year & & $2016-2017$ & \multicolumn{3}{|c|}{$2016-2017$} \\
\hline Semester & - & spring & fall & spring & \\
\hline Course / Course ID & - & $\begin{array}{l}\text { Linear algebra II } \\
\text { (NMAI058) }\end{array}$ & Linear algebra I (NAMI057) & $\begin{array}{l}\text { Linear algebra II } \\
\text { (NMAI058) }\end{array}$ & \\
\hline $\begin{array}{l}\text { Randomization of } \\
\text { oral part form } \\
\text { assignment }\end{array}$ & - & $\begin{array}{l}\text { Randomized } \\
\text { option to change form }\end{array}$ & $\begin{array}{l}\text { Randomized } \\
\text { no form changing }\end{array}$ & $\begin{array}{l}\text { Randomized } \\
\text { option to change form }\end{array}$ & \\
\hline Form of oral part & - & MCM and Linear form & MCM and Linear form & MCM and Linear form & \\
\hline $\begin{array}{l}\text { Additional selection } \\
\text { condition }\end{array}$ & - & $\begin{array}{l}\text { Only data after student at } \\
\text { least one times attempt } \\
\text { MCM form }\end{array}$ & $\begin{array}{l}\text { Only data after student at } \\
\text { least one times attempt } \\
\text { MCM form }\end{array}$ & $\begin{array}{l}\text { Only data after student at } \\
\text { least one times attempt } \\
\text { MCM form }\end{array}$ & \\
\hline Assumption & - & $\begin{array}{l}\text { Students have significant } \\
\text { experience with oral form } \\
\text { examination }\end{array}$ & $\begin{array}{l}\text { Students NOT have to have } \\
\text { significant experience with } \\
\text { oral form examination }\end{array}$ & $\begin{array}{l}\text { Students have significant } \\
\text { experience with oral form } \\
\text { examination }\end{array}$ & \\
\hline $\mathrm{n}$ & - & & 6 & & 75 \\
\hline Count changed form & - & & ( & & 3 \\
\hline $\begin{array}{l}\text { Relative count of } \\
\text { examination changed } \\
\text { form }\end{array}$ & - & & 0.0 & & .04 \\
\hline
\end{tabular}

Table 7: Data set 3 and Data set 4 specification

\begin{tabular}{|c|c|c|c|c|c|}
\hline Data set & \multicolumn{2}{|r|}{ Data set 3} & \multicolumn{3}{|c|}{ Data set 4} \\
\hline School year & & $2016-2017$ & 2016 & -2017 & \\
\hline Semester & - & spring & fall & spring & \\
\hline Course / Course ID & - & $\begin{array}{l}\text { Linear algebra II } \\
\text { (NMAI058) }\end{array}$ & $\begin{array}{l}\text { Linear algebra I } \\
\text { (NAMI057) }\end{array}$ & $\begin{array}{l}\text { Linear algebra II } \\
\text { (NMAI058) }\end{array}$ & \\
\hline $\begin{array}{l}\text { Randomization of oral part } \\
\text { form assignment }\end{array}$ & - & $\begin{array}{l}\text { Randomized } \\
\text { option to change form }\end{array}$ & $\begin{array}{l}\text { Randomized } \\
\text { no form changing }\end{array}$ & $\begin{array}{l}\text { Randomized } \\
\text { option to change form }\end{array}$ & \\
\hline Form of oral part & - & MCM form only & MCM form only & MCM form only & \\
\hline Additional selection condition & - & MCM form & MCM form & MCM form & \\
\hline Assumption & - & $\begin{array}{l}\text { Students have significant } \\
\text { experience with oral form } \\
\text { examination }\end{array}$ & $\begin{array}{l}\text { Students NOT have to have } \\
\text { significant experience with } \\
\text { oral form examination }\end{array}$ & $\begin{array}{l}\text { Students have significant } \\
\text { experience with oral form } \\
\text { examination }\end{array}$ & \\
\hline $\begin{array}{l}\mathrm{n} \\
\text { (for each set) }\end{array}$ & - & 54 & 62 & & 54 \\
\hline Count changed form & - & 3 & 0 & & 3 \\
\hline $\begin{array}{l}\text { Relative count of changed } \\
\text { examination form }\end{array}$ & - & 0.06 & 0.00 & & 0.06 \\
\hline
\end{tabular}

\subsection{Results - objective}

To investigate hypotheses, we use a one-sample t-test and descriptive statistics.

Results of Hypothesis $\mathrm{H} 1$ and Hypothesis $\mathrm{H} 2$ for Data set 1 and Data set 2 are summarized in Table 8. 


\begin{tabular}{|c|c|c|c|c|c|}
\hline \multicolumn{6}{|c|}{ As measured by students' questionnaires self-reports } \\
\hline \multicolumn{2}{|c|}{ Likert scale -3 (worst) -+3 (best) } & $t$ & $p$ & $d f$ & $95 \% C I$ \\
\hline \multirow{2}{*}{$\begin{array}{l}\text { Data set } 1 \\
\text { Data } 2017 \\
\text { NMAI058 only, } \\
\text { restricted data }\end{array}$} & $\begin{array}{l}\text { Hypothesis } 1(\mathrm{H} 1) \text { : MCM shares structural } \\
\text { understanding better than linear form. }\end{array}$ & -13.58 & $<0.001$ & 70 & [-Inf -2.64$]$ \\
\hline & $\begin{array}{l}\text { Hypothesis } 2 \text { (H2): MCM shares local } \\
\text { understanding at least as well as linear form }\end{array}$ & 6.77 & 1.00 & 70 & [-Inf 1.72$]$ \\
\hline \multirow{2}{*}{$\begin{array}{l}\text { Data set } 2 \\
\text { Data } 2017 \\
\text { NMAI057 + NMAI058 }\end{array}$} & $\begin{array}{l}\text { Hypothesis } 1 \text { (H1): MCM shares structural } \\
\text { understanding better than linear form. }\end{array}$ & -17.85 & $<0.001$ & 130 & [-Inf -2.69$]$ \\
\hline & $\begin{array}{l}\text { Hypothesis } 2(\mathrm{H} 2) \text { : MCM shares local } \\
\text { understanding at least as well as linear form }\end{array}$ & 7.88 & 1.00 & 130 & [-Inf 1.47] \\
\hline
\end{tabular}

Students claim that MCM share structural understanding better than the linear form in Data set 1 and Data set 2, so H1 is supported in both data sets.

Contrary to MCM not share local details at least, as well as linear form in Data set1 and Data, set 2, so $\mathrm{H} 2$ is rejected in both data sets.

From 95\% confidence interval values follow that MCM form shares at least 2,64 grade better structural understanding than linear form and at least 1,72 worse local understanding given Data set 1 and MCM shares 2,69 grade better structural understanding than linear form and at least over 1,47 worse local understanding given Data set 2, all grades measured on 7 steps of Likert scale and given by the difference of form sharing means.

Descriptive statistics to $\mathrm{H} 1$ and $\mathrm{H} 2$ hypotheses are given in Table 9.

Table 9: Hypothesis $H 1$ and $H 2$ descriptive statistics

\begin{tabular}{|c|c|c|c|c|c|}
\hline \multicolumn{6}{|c|}{ As measured by students' questionnaires self-reports } \\
\hline Likert scale -3 (worst) -+3 (best) & & $\mathrm{n}$ & NA & Mean & SD \\
\hline \multirow{4}{*}{$\begin{array}{l}\text { Data set } 1 \\
\text { Data } 2017 \\
\text { NMAI058 only, restricted data }\end{array}$} & MCM form shares structural understanding & 71 & 4 & 1.98 & 0.96 \\
\hline & MCM form shares local undestanding & 71 & 4 & -0.17 & 1.07 \\
\hline & Linear form shares structural understanding & 71 & 4 & -1.03 & 1.19 \\
\hline & Linear form shares local understanding & 71 & 4 & 1.21 & 1.08 \\
\hline \multirow{4}{*}{$\begin{array}{l}\text { Data set } 2 \\
\text { Data } 2017 \\
\text { NMAI057 + NMAI058 }\end{array}$} & MCM form shares structural understanding & 131 & 7 & 1.96 & 1.02 \\
\hline & MCM form shares local undestanding & 131 & 7 & -0.09 & 1.08 \\
\hline & Linear form shares structural understanding & 131 & 7 & -1.00 & 1.28 \\
\hline & Linear form shares local understanding & 131 & 7 & 1.12 & 1.16 \\
\hline
\end{tabular}

Figure 2 depicts a histogram of absolute values distribution of students' self-report attitude to structural and local understanding sharing ability, given by structural and linear form for Data set 1 and Data set2. Figure 3 visualizes the histogram in a relative manner. 
Figure 2: Histograms - students answer to ability form to share structural understanding and locals - absolute counts

MCM form shares structural understanding

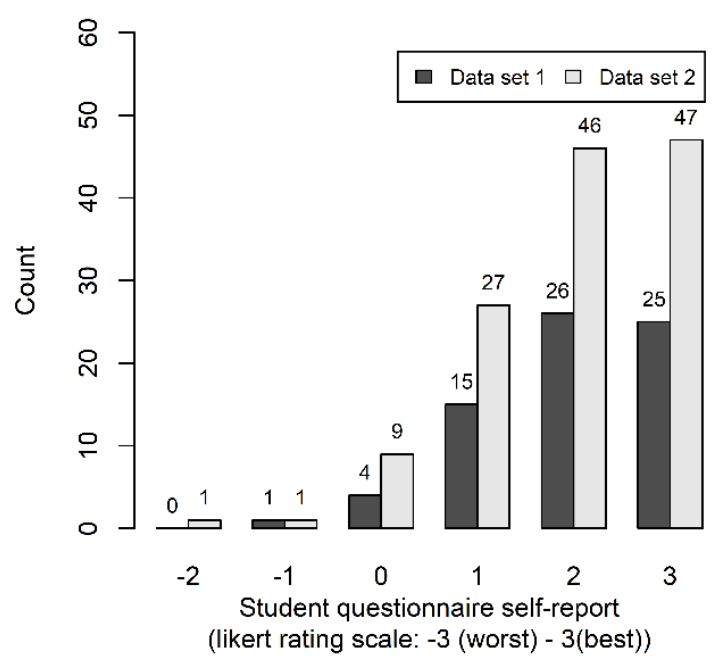

Linear form shares structural understanding

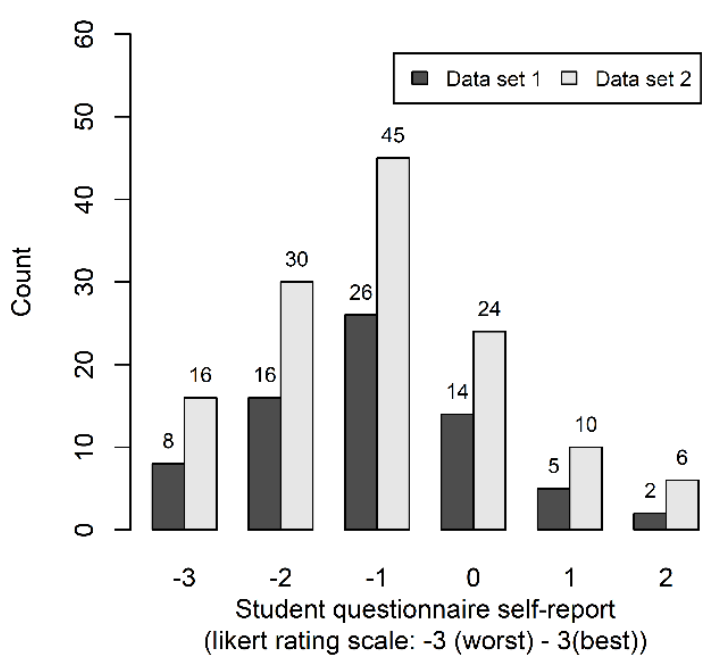

MCM form shares local understanding

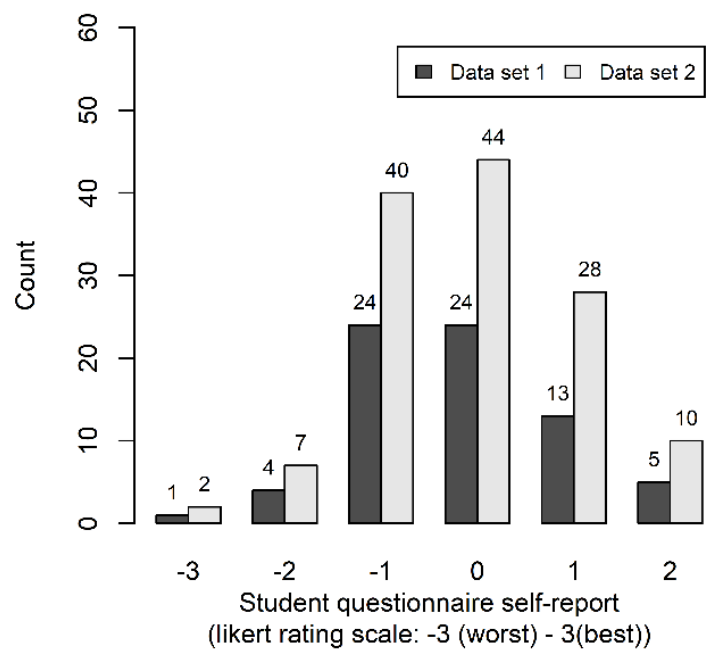

Linear form shares local understanding

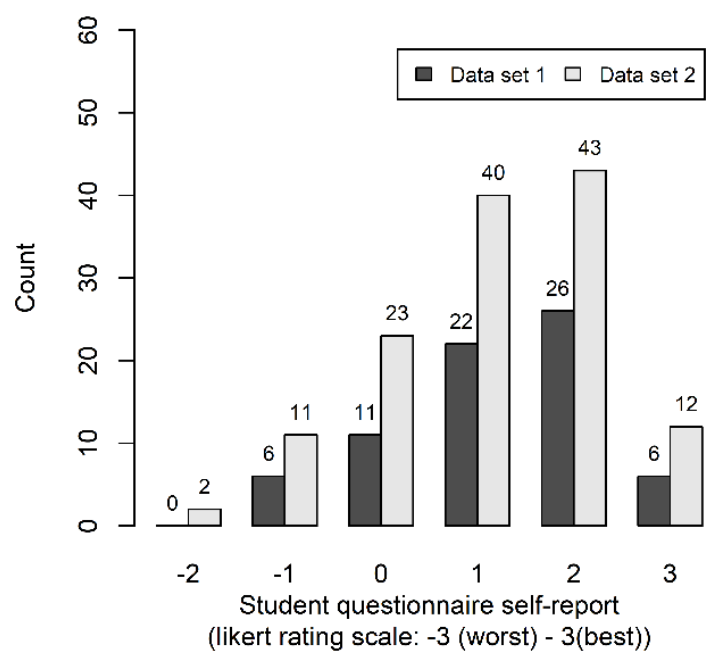


MCM form shares structural understanding

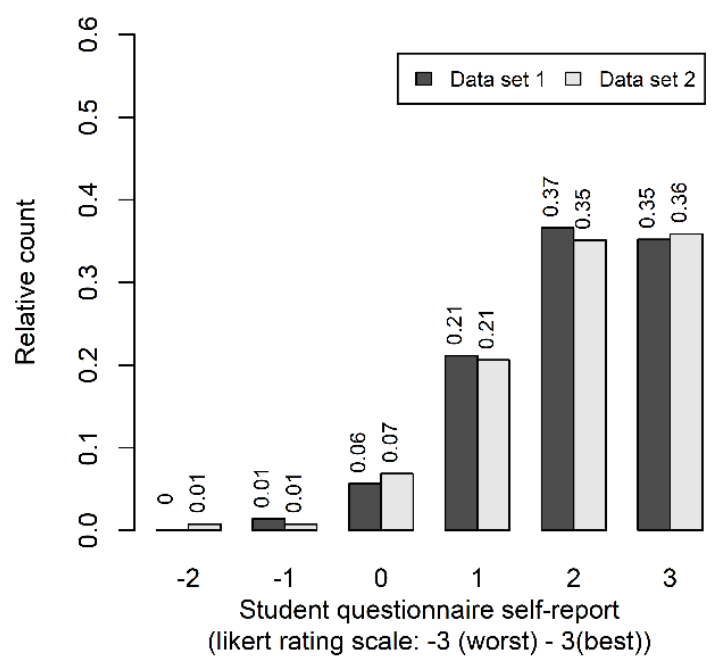

Linear form shares structural understanding

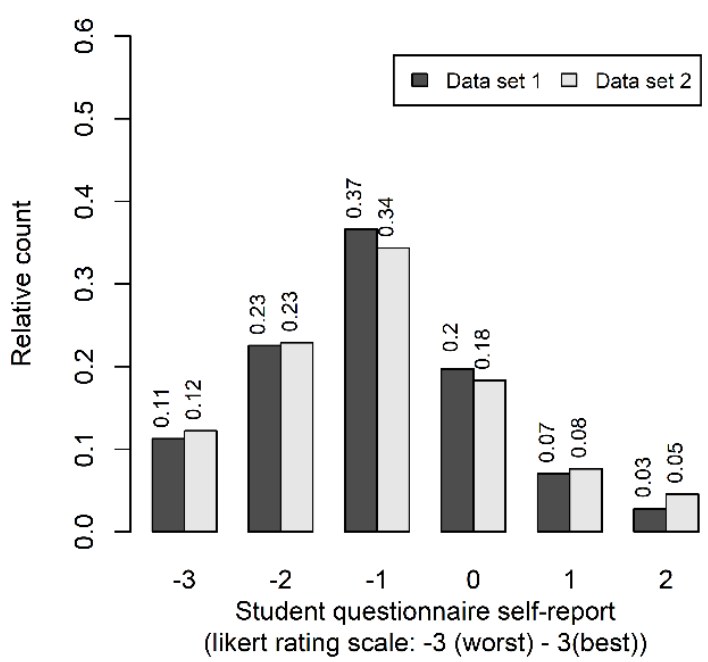

MCM form shares local understanding

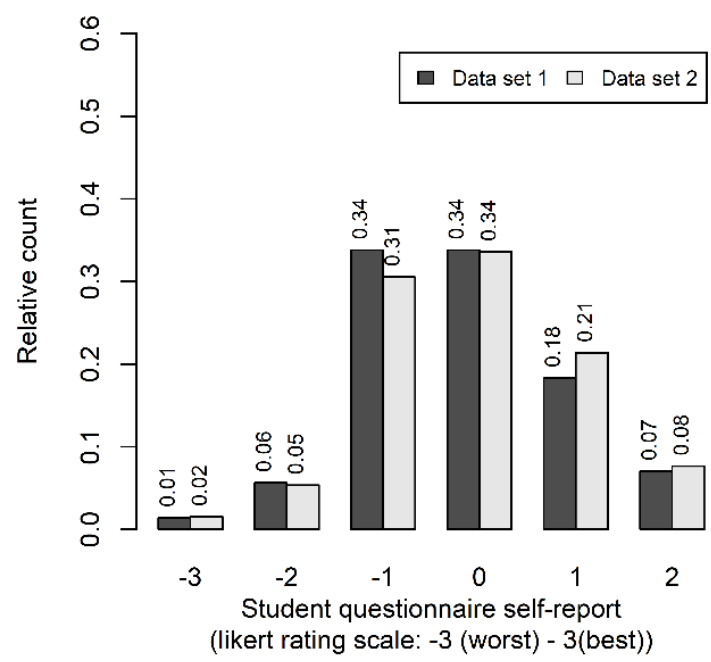

Linear form shares local understanding

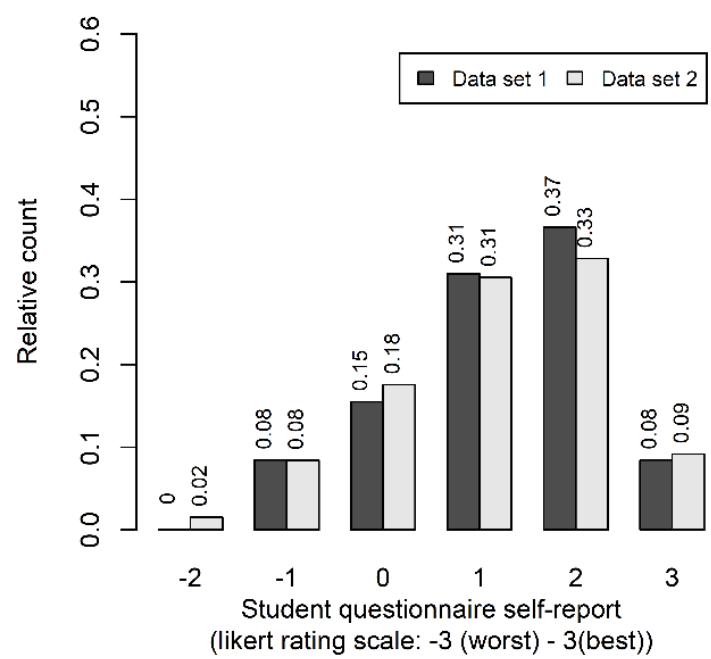

Results and descriptive statistics of the Support hypothesis (SH1) for Data set 3 and Data set 4 are summarized in Table 10.

Table 10: Summarize support hypothesis SH1 test results and descriptive statistics for Data set 3 and Data set 4

\begin{tabular}{|c|c|c|c|c|c|c|c|c|c|}
\hline \multicolumn{10}{|c|}{ As measured by students' questionnaires self-reports } \\
\hline \multicolumn{2}{|c|}{$\begin{array}{l}\text { As measured by students' questionnaires selt-reports } \\
\text { Likert scale }-3 \text { (less objective) }-+3 \text { (more objective) }\end{array}$} & $\mathrm{n}$ & NA & Mean & $\mathrm{SD}$ & $t$ & $p$ & $d f$ & $95 \% C I$ \\
\hline $\begin{array}{l}\text { Data set } 3 \\
\text { Year } 2017 \\
\text { Track NMAI058 only }\end{array}$ & $\begin{array}{l}\text { (HS1) Oral part of examination } \\
\text { using MCM is at least as objective } \\
\text { as other forms of oral exam at the } \\
\text { university }\end{array}$ & 52 & 2 & 1.17 & 1.20 & 7.05 & $<0.001$ & 51 & [0.89 Inf] \\
\hline $\begin{array}{l}\text { Data set } 4 \\
\text { Year } 2017 \\
\text { Track NMAI057 + NMAI058 }\end{array}$ & $\begin{array}{l}\text { (HS1) Oral part of examination } \\
\text { using MCM is at least as objective } \\
\text { as other forms of oral exam at the } \\
\text { university }\end{array}$ & 109 & 7 & 1.03 & 1.18 & 9.08 & $<0.001$ & 108 & [0.84 Inf] \\
\hline
\end{tabular}


Students claim that the oral part of examination using MCM is at least as objective as other forms of the oral examinations at the university in both data sets, so SH1 is supported.

Correlation between final student oral exam score and students declared oral part MCM exam form objectivity is $R_{a d j}^{2}=-0.018$ for Data set 3 and $R_{a d j}^{2}=-0.007$ for Data set 4 , both correlations are statistically low. There is no statistically significant evidence of behavior when a student scores structural oral examination higher in pursue of the better final grade for both data sets, the depiction of relation sees Figure 4: Relation between overall student examination score and student perceive objectivity of MCM form oral exam

Figure 4: Relation between overall student examination score and student perceive objectivity of MCM form oral exam
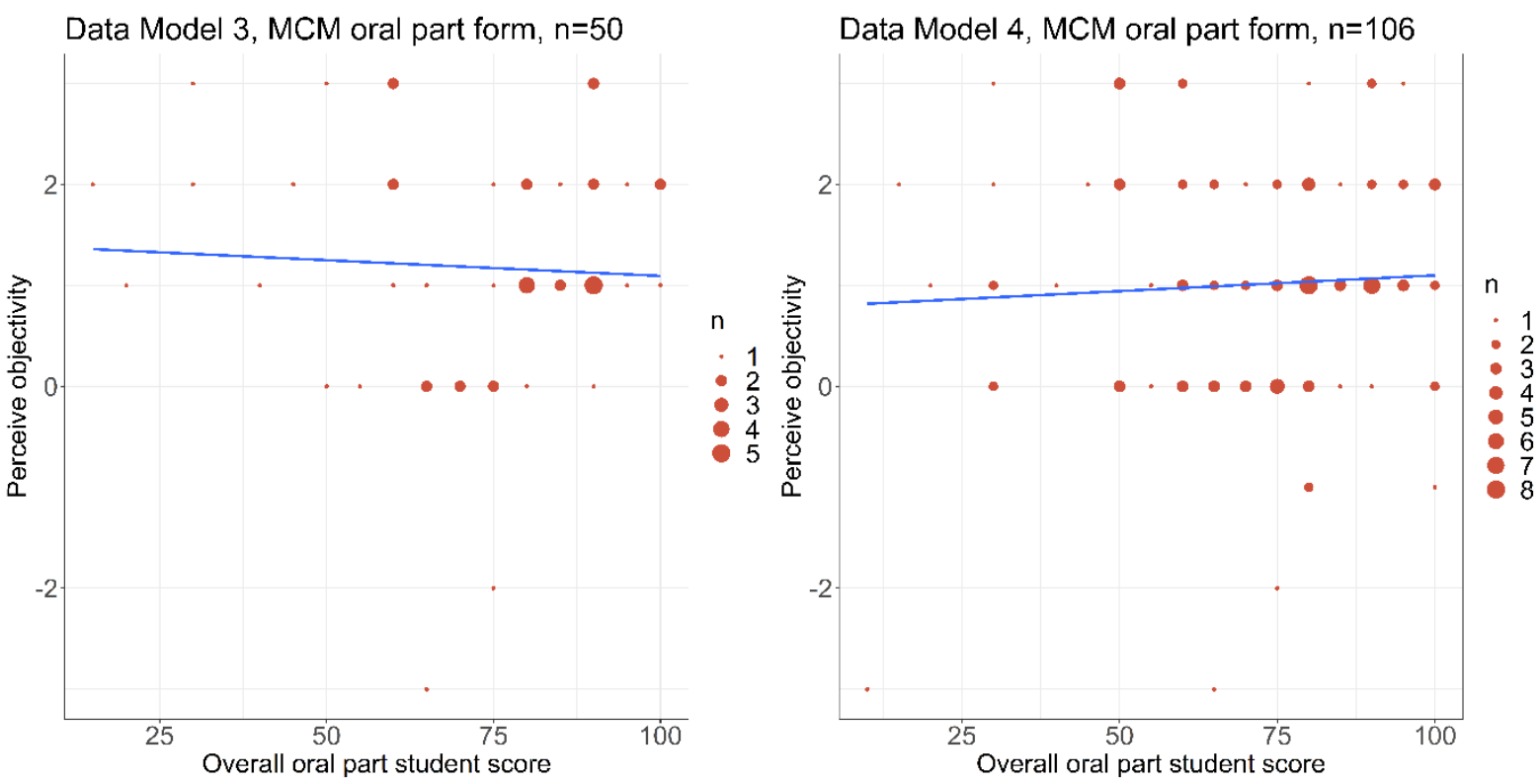

Results and descriptive statistics of the Support hypothesis (SH2) for Data set 3 and Data set 4 are summarized in Table 11.

Table 11: Summarize support hypothesis SH2 test results and descriptive statistics for Data set 3 and Data set 4

\begin{tabular}{|c|c|c|c|c|c|c|c|c|c|}
\hline \multicolumn{10}{|c|}{ As measured by students' questionnaires self-reports } \\
\hline Likert scale -3 (worst) - & +3 (best) & $\mathrm{n}$ & NA & Mean & SD & $t$ & $p$ & $d f$ & $95 \% C I$ \\
\hline $\begin{array}{l}\text { Data set } 3 \\
\text { Data } 2017 \\
\text { NMAI058 only }\end{array}$ & $\begin{array}{l}\text { (SH2) MCM examine structural } \\
\text { understanding better than other } \\
\text { forms exam you attended }\end{array}$ & 130 & 8 & 1.75 & 0.99 & 20.22 & $<0.001$ & 129 & {$[1.61 \mathrm{Inf}]$} \\
\hline $\begin{array}{l}\text { Data set } 4 \\
\text { Data } 2017 \\
\text { NMAI057 + NMAI058 }\end{array}$ & $\begin{array}{l}\text { (SH2) MCM examine structural } \\
\text { understanding better than other } \\
\text { forms exam you attended }\end{array}$ & 71 & 4 & 1.80 & 0.90 & 16.80 & $<0.001$ & 70 & {$\left[\begin{array}{ll}1.62 & \text { Inf }\end{array}\right]$} \\
\hline
\end{tabular}

Students claim that MCM examines structural understanding better than other forms of exams he/she attended, so $\mathrm{SH} 2$ is supported. 
Moreover, Figure 5 depicts a histogram of students' perception of the whole exam difficulty compared to their expectations.

Figure 5: Student self-report questionnaire Likert scale rating histogram of perceiving overall difficulty exam (written and oral part)

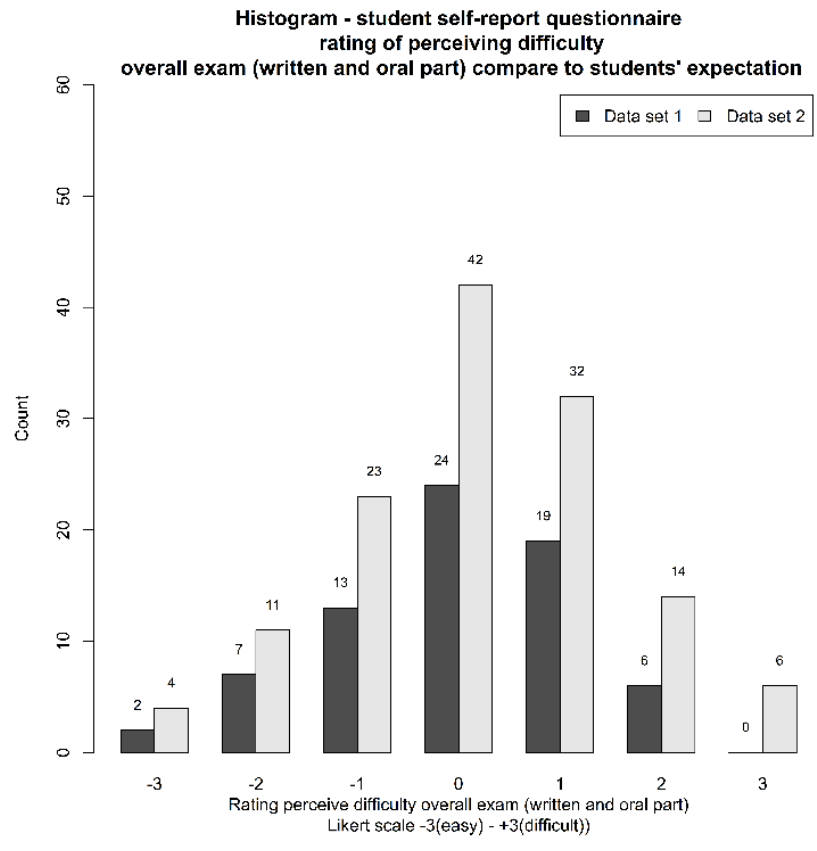

\subsection{Examiners subjective, case report and preliminary observation}

Examiners observed surprisingly well-done MCM maps, although they expected students to have no or low experience or practice with concept mapping visualization of structured understanding. The expectation is based on the fact that the course and lecturers' notes were presented linearly.

After the study, examiners concur they obtained significant comprehension of students' understanding of linear algebra from their MCMs and were surprised by the diversity of concept map structures and thus their personal domain understanding.

Major distinctive phenomena of MCM and linear form in the assessment was explicit visualization of relations between facts in the case of MCM. Visualized relations could be directly asked or referred to by the student or examiner, contrary to mostly verbally referenced relations in the case of linear form. To summarize, what is visualized takes students' and examiners' evaluative focus. MCM adds support for structural understanding compared to linear form. 


\section{Discussion}

\subsection{Educational implication}

Given the different abilities to share structural and linear understanding, there is a statistically significant difference in students' perception between MCM and linear form; thus examiner could influence focus on structural and local understanding by choosing the suitable form for the purpose.

\subsection{Limitation and future directions}

\subsubsection{Limitation}

The degree of evidence of visualization of personal student understanding is limited by the sort of participants in this study: undergraduate student of one (computer science) study branch, one university, and in the mathematical field. The substantive limitation of the study is a self-report form of objective data and evidence.

Students performing the examination at a later date may have different initial experiences and knowledge about MCM (talks with colleagues who had an examination before; exam repetition) and could think over preparation. Changing experience during the experiment could even influence examiners, who were, we believe, more stable, with fixed preceding proof of concept and trial runs.

The influence of exam repetition is not distinguished.

The fall semester is mostly the first freshman students' experience with university studies, and there is limited experience with other forms of examination, including oral examination. The evidence-based on these students' experiences are used for hypothesis validation.

There is no objective measurement of what portion of student structural and local understanding was shared by oral part preparation and what portion by discussion. Although the experiment setting was standardized, there is naturally personal and interpersonal discussion limitation.

Due to voluntary agreement, experimental data contain NA values.

Two examiners were principal investigators and authors of this paper.

\subsubsection{Future directions}

Though the study was focused on student understanding shared by creating and explaining a modified concept map, there are more ways to use the structural diagramming concept: e.g., to complete a partially done diagram, correction of the diagram, etc.

It is challenging to use or create objectivized scoring method. 


\subsubsection{Conclusion}

We divide personal mathematical understanding into local, structural understanding and craft. We modify the concept map assessment tool by setting local understanding to nodes, structural understanding to multilink connections without a hierarchal fashion. The modified concept map was compared to the standard linear form of examination in the ability to share structural and local understanding in the oral examination part.

Through a three-year study, we collected almost 300 (counting proof of concept and trial runs) data points from the regular final examination of university freshman students in obligatory Linear algebra I and II courses, with no benefits for their participation. To study the testing hypothesis, randomized data from regular Fall and Spring runs in the year 20162017 were used, split into data sets given form of randomization and student experience with the examination.

Concerning self-report questionnaire student data, the MCM method joined with the student-examiner discussion method shares statistically significantly better (given 95\% confidence interval 2,64 in 7-grade Likert scale) structural understanding than linear form. Further, the MCM method does not share local understanding equally well; it shares (given a 95\% confidence interval given 1,75 in 7-grade Likert scale) less than the linear form for more restrictive data sets.

Students claim that the MCM oral examination form is almost as objective as other oral examination forms they attended through their studies.

Surprisingly, students created good modified concept maps, although we assumed their low to none practical experience with concept mapping.

The practical impact of the experimentation for assessments can shortly be described as "what is depicted is focused," which leads to the examiner driving proportion of structural and local understanding tested through the examination.

\section{Declaration of interest}

The authors of this study were a Ph.D. part of examiners.

\section{Funding}

Goodwill and support of lecturer of Linear algebra courses fund this study. No other funding was used in this study.

\section{Acknowledgments}




\section{References}

1. Anohina-Naumeca, Alla \& Grundspenkis, Janis. (2009). Scoring Concept Maps: an Overview. Proceedings of the 2009 International Conference on Computer Systems and Technologies and Workshop

2. Ausubel, D. G. (1963). Cognitive Structure and the Facilitation of Meaningful Verbal Learning1. Journal of Teacher Education, 14(2), 217-222. https://doi.org/10.1177/002248716301400220

3. Ausubel, D. P. (1968). Educational psychology: A cognitive view. New York: Holt, Rinehart and Winston.

4. Ausubel, D. P. (2000). The acquisition and retention of knowledge: A cognitive view. Boston, MA: Kluwer Academic Publishers.

5. Chei-Chang Chiou (2009). Effects of concept mapping strategy on learning performance in business and economics statistics, Teaching in Higher Education, 14:1, 55-69, https://doi.org/10.1080/13562510802602582

6. Daugherty, Jenny L.; Custer, Rodney L.; Dixon, Raymond A. (2012). Mapping Concepts for Learning and Assessment. Technology and Engineering Teacher, v71 n8 p10-14 May-Jun 2012

7. Dochy, F. J. R. C. (1996). Assessment of domain-specific and domain-transcending prior knowledge: Entry assessment and the use of profile analysis. In M. Birenbaum \& F. J. R. C. Dochy (Eds.), Evaluation in education and human services. Alternatives in assessment of achievements, learning processes and prior knowledge (pp. 227264). New York, NY, US: Kluwer Academic/Plenum Publishers. https://doi.org/10.1007/978-94-011-0657-3_9

8. Kevin M. Roessger, Barbara J. Daley, Duaa A. Hafez (2018). Effects of teaching concept mapping using practice, feedback, and relational framing, Learning and Instruction, Volume 54, https://doi.org/10.1016/j.learninstruc.2018.01.011.

9. Marshall, J. (1968). James Deese, The Structure of Associations in Language and Thought. Baltimore: The Johns Hopkins Press, 1965, Pp. ix 216. Journal of Linguistics, 4(1), 131-133. DOI:10.1017/S0022226700001754

10. Novak, J., Gowin, D., \& Kahle, J. (1984). Learning How to Learn. Cambridge: Cambridge University Press. https://doi.org/10.1017/CBO9781139173469

11. Novak, Joseph D. (1998). Learning, Creating and Using Knowledge. Mahwah NJ: Erlbaum 
12. Novak, Joseph D., Cañas. Alberto J. (2008). The Theory Underlying Concept Maps and How to Construct and Use Them. Retrieved from:

http://cmap.ihmc.us/docs/theory-of-concept-maps

13. Riesco, M., Fondon, M. D., \& Alvarez, D. (2008). Designing degrees: Generating concept maps for the description of relationships between subjects. Concept Mapping: Connecting Educators, Proc. of the Third Int. Conference on Concept Mapping, Tallinn, Estonia \& Helsinki, Finland 2008

14. Ruiz-Primo, M. A. and Shavelson, R. J. (1996), Problems and issues in the use of concept maps in science assessment. J. Res. Sci. Teach., 33: 569-600. https://doi.org/10.1002/(SICI)1098-2736(199608)33:6<569::AID-TEA1>3.0.CO;2-M

15. Ruiz-Primo, Maria \& Schultz, Susan \& Shavelson, Richard. (2001). Comparison of the Reliability and Validity of Scores from Two Concept-Mapping Techniques. Journal of Research on Science Teaching. 38. 260-278.

DOI: 10.1002/1098-2736(200102)38:23.0.CO;2-F.

16. Ruiz-Primo, Maria (2004). Examining concept maps as an assessment tool. Concept Maps: Theory, Methodology, Technology, Proc. of the Firts Int. Conference on Concept Mapping, Pamplona, Spain 2004

17. Sally P.W. Wu, Martina A. Rau. 2018. Effectiveness and efficiency of adding drawing prompts to an interactive educational technology when learning with visual representations. Learning and Instruction 55 (2018) 93-104.

18. Schroeder, N.L., Nesbit, J.C., Anguiano, C.J. et al. (2018), Studying and Constructing Concept Maps: a Meta-Analysis, Educ Psychol Rev, 30: 431. https://doi.org/10.1007/s10648-017-9403-9

19. Stoddart, T. (2006). Using concept maps to assess the science understanding and language production of English language learners. Concept maps: Theory, methodology, technology: Proceedings of the second international conference on concept mapping, Costa Rica: San José.

20. Vagliardo, J. J. (2004). Substantive knowledge and mindful use of logarithms: A conceptual analysis for mathematics education. Concept Maps: Theory, Methodology, Technology; Proc. of the First Int. Conference on Concept Mapping` Pamplona, Spain

21. West, D. C., Park, J. K., Pomeroy, J. R. and Sandoval, J. (2002), Concept mapping assessment in medical education: a comparison of two scoring systems. Medical Education, 36: 820-826. https://doi.org/10.1046/j.1365-2923.2002.01292.x

22. Yuruk, N., Beeth, M.E. \& Andersen, C. Res Sci Educ (2009). Analyzing the Effect of Metaconceptual Teaching Practices on Students' Understanding of Force and Motion Concepts, Research in Science Education, Volume 39, Issue 4, pp 449-475, https://doi.org/10.1007/s11165-008-9089-6 
23. Anderson, Lorin W.; Krathwohl, David R., eds. (2001). A taxonomy for learning, teaching, and assessing: A revision of Bloom's taxonomy of educational objectives. New York: Longman. ISBN 978-0-8013-1903-7. 


\section{A. Appendix - Students preparation examples}

\section{a. MCM form of examination examples}

Figure 6: Student example MCM form preparation - example 1

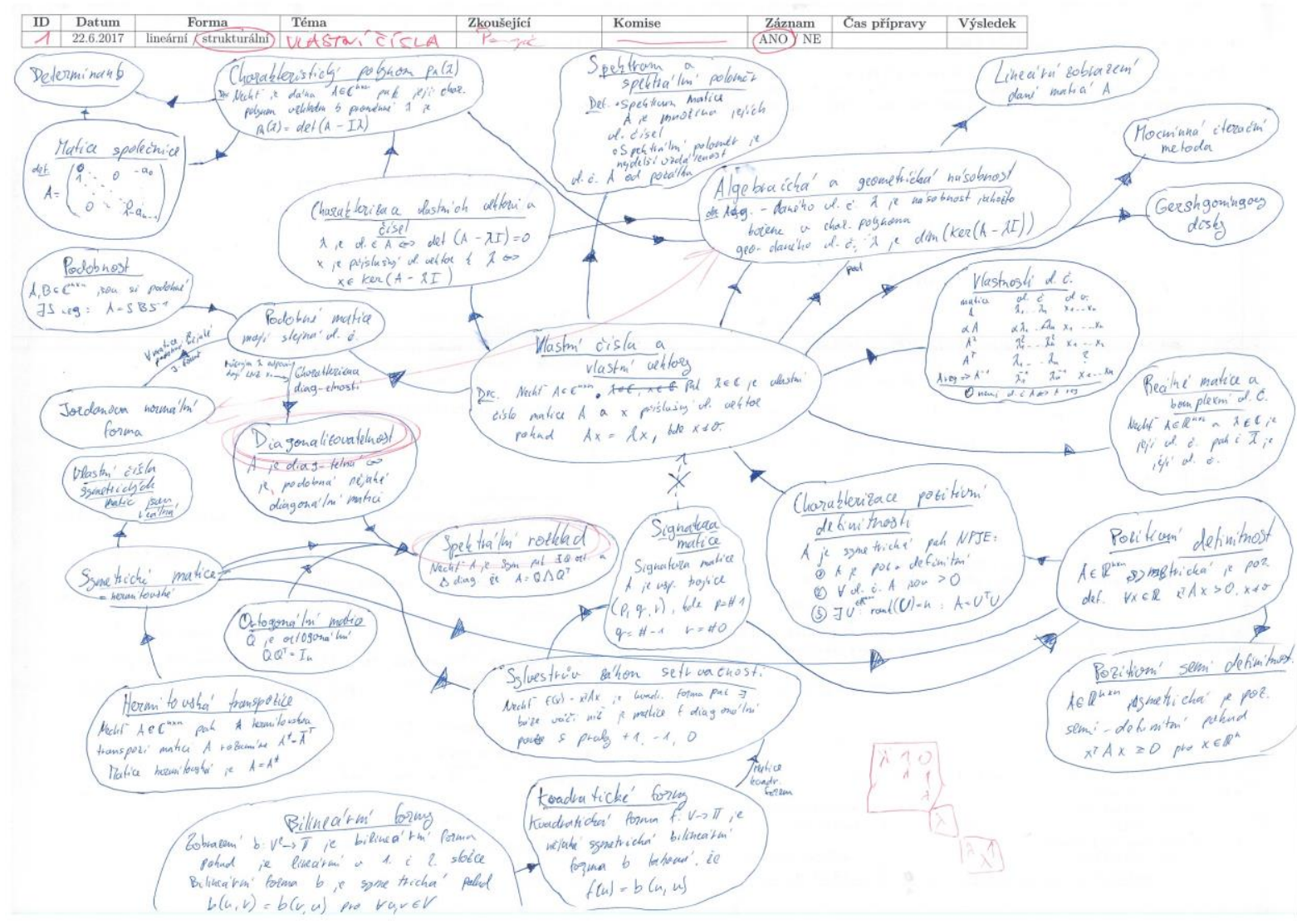


Figure 7: Student example MCM form preparation - example 2

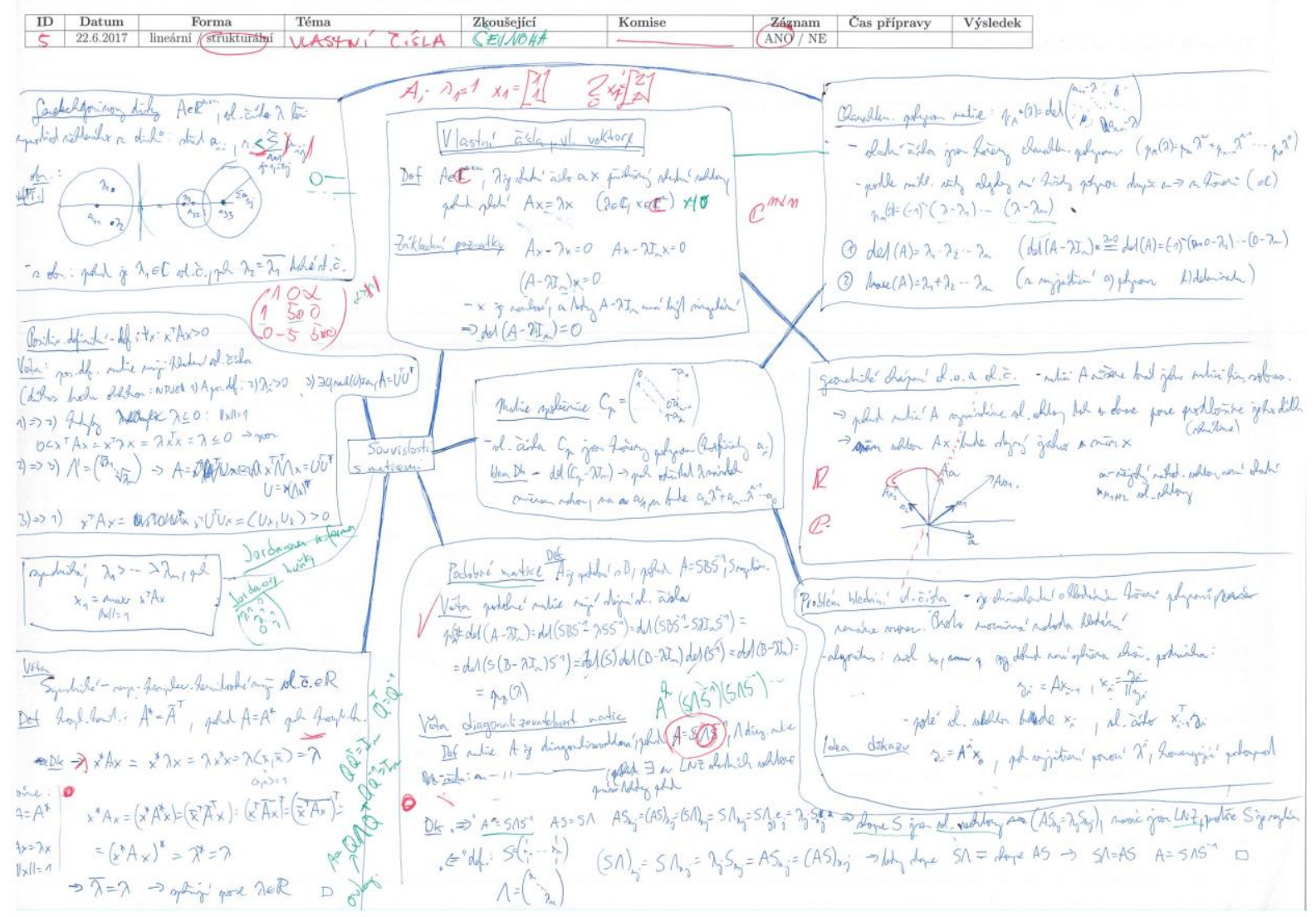


Figure 8: Student example MCM form preparation - example 3

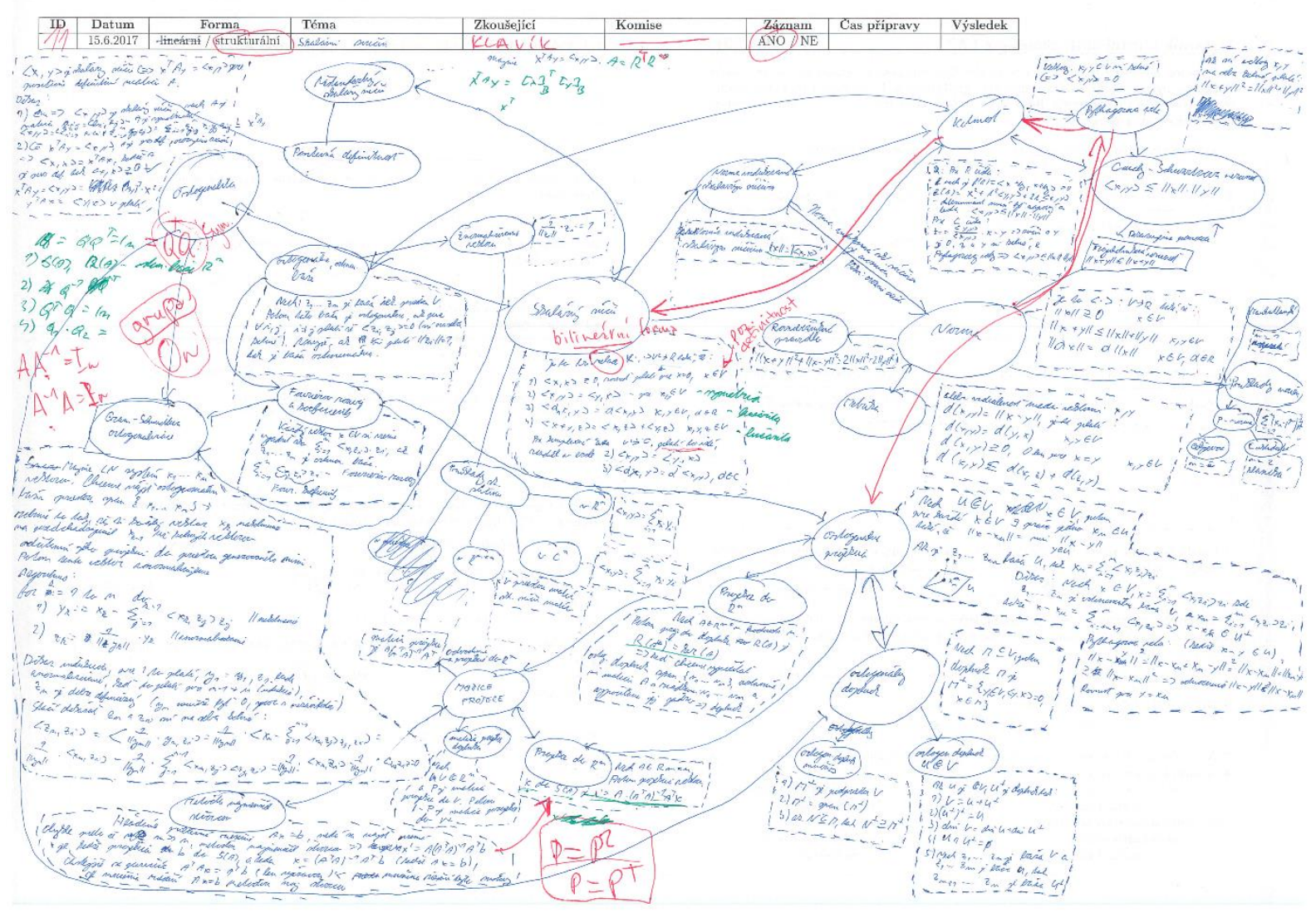

\section{b. Linear form examination example}

Figure 9: Student example linear form preparation - exemple 1 


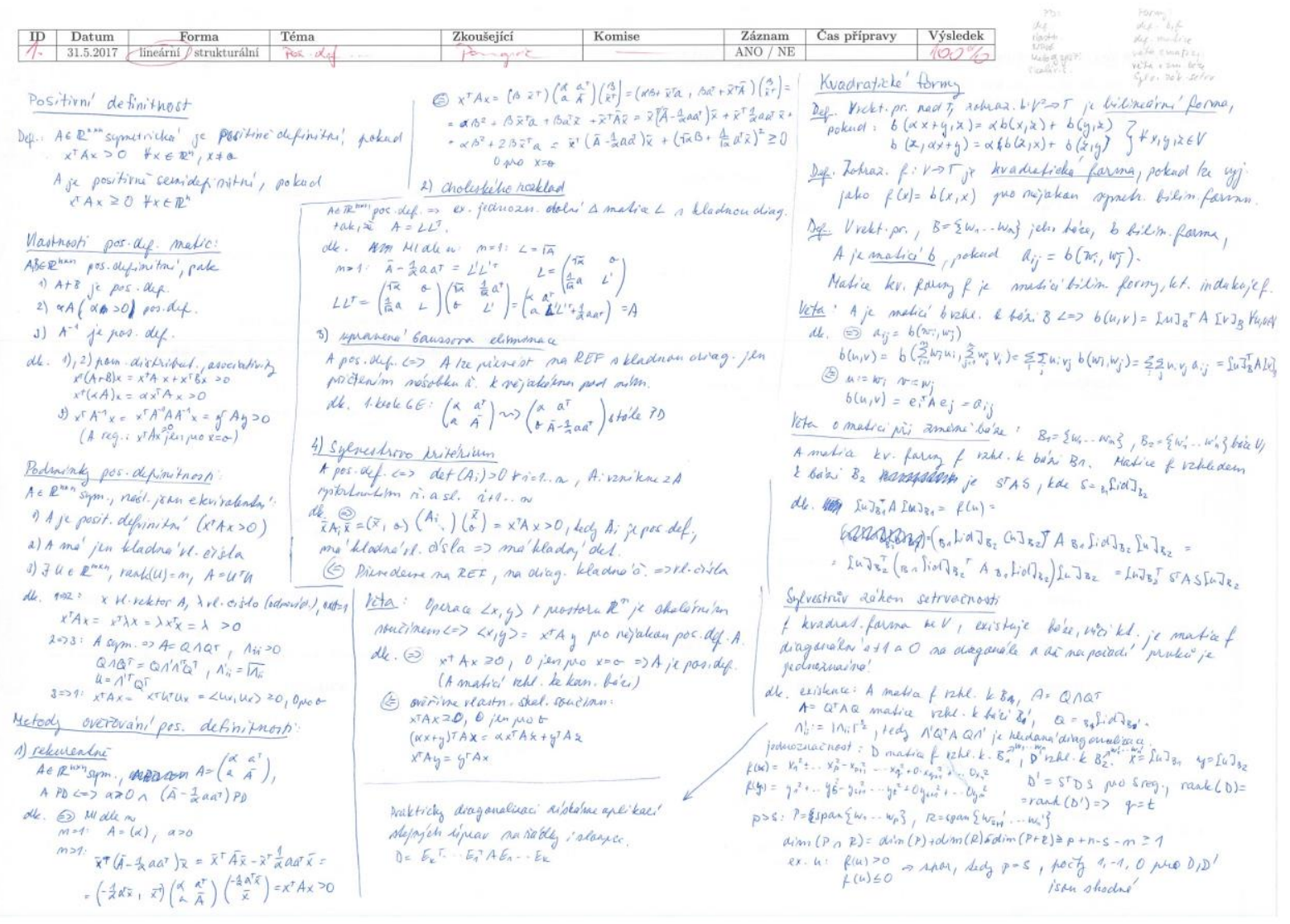


Figure 10: Student example linear form preparation -example 2-part 1

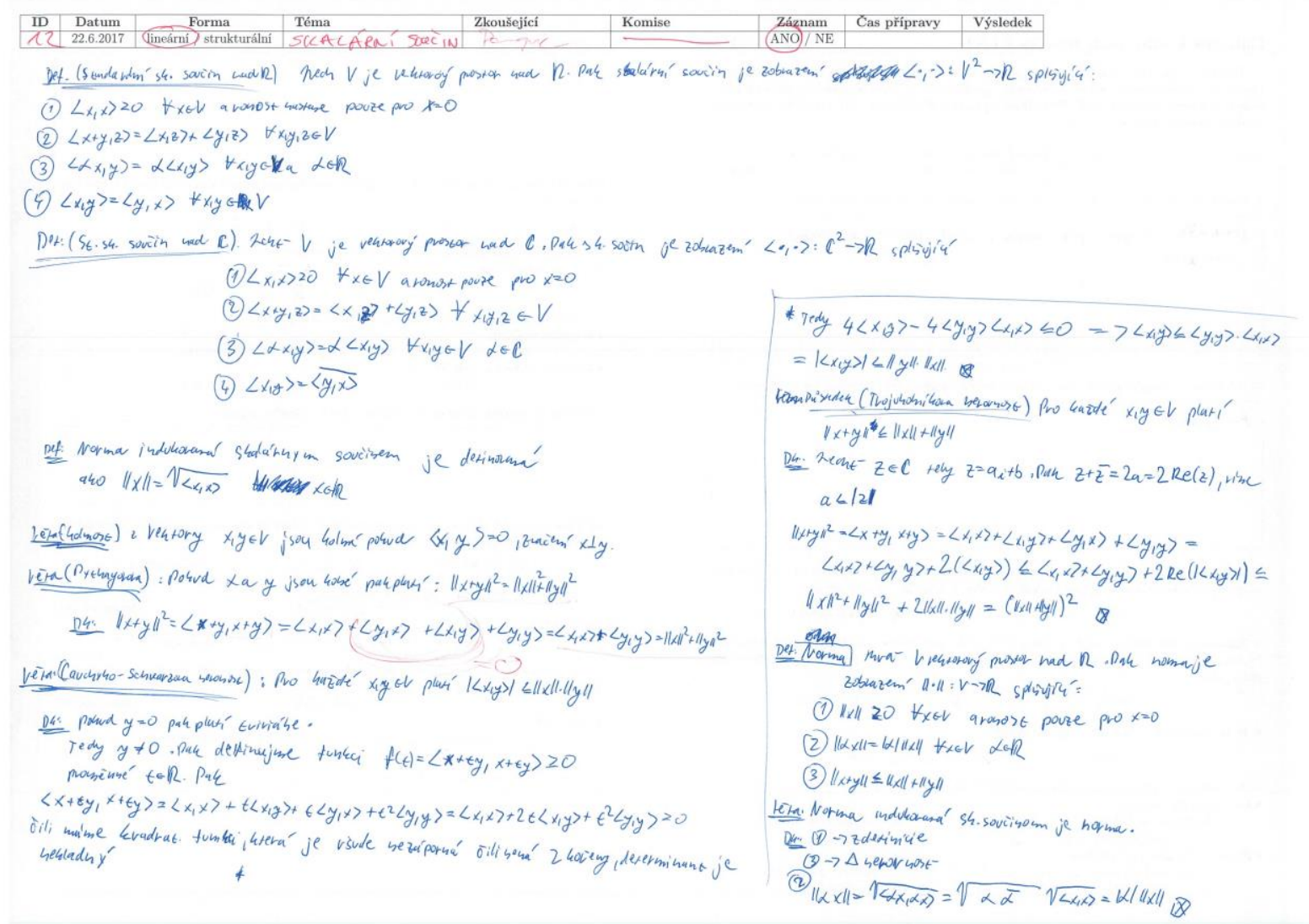

Figure 11: Student example linear form preparation - highly rated-part 2

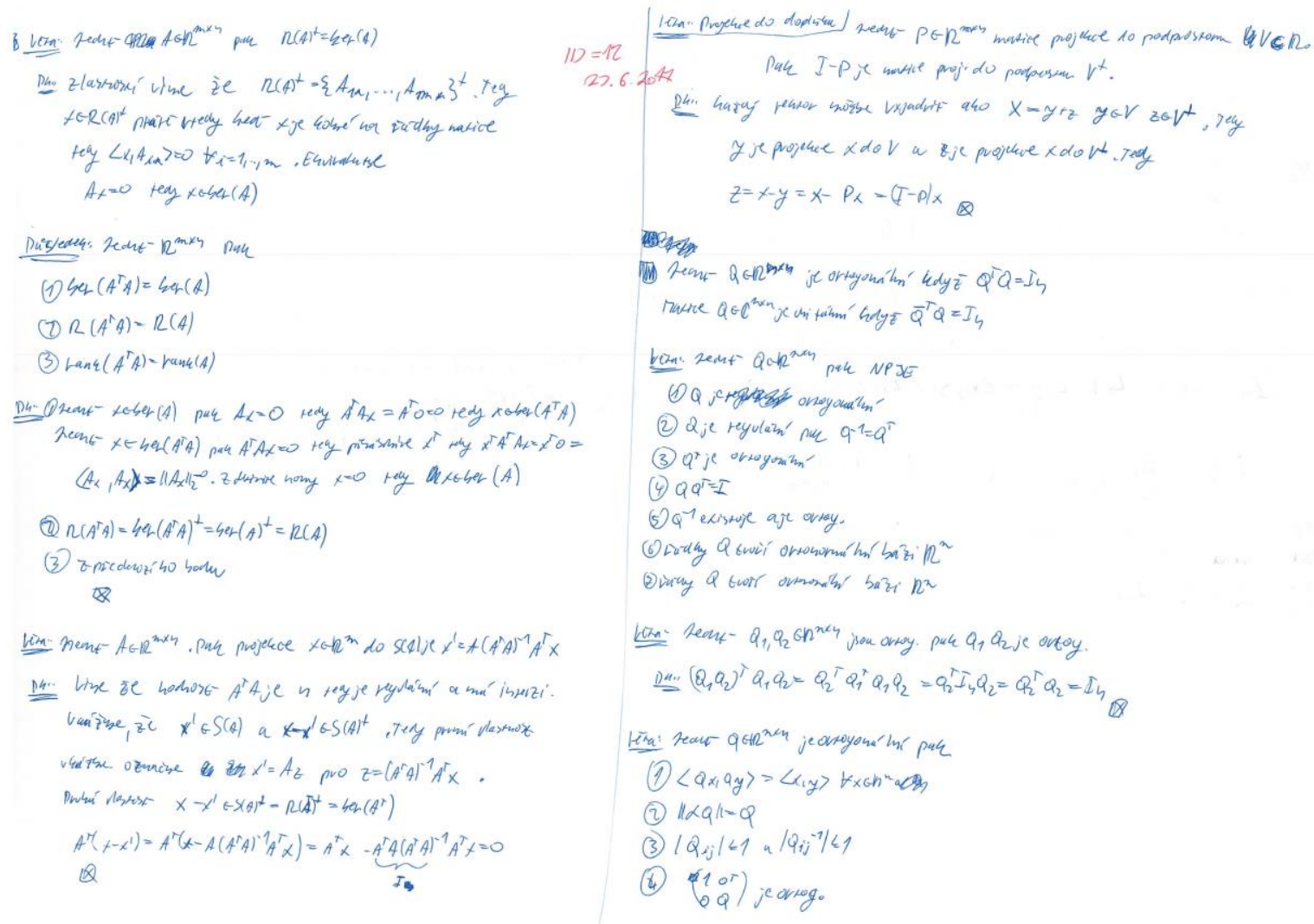


Figure 12: Student example linear form preparation - highly rated-part 3

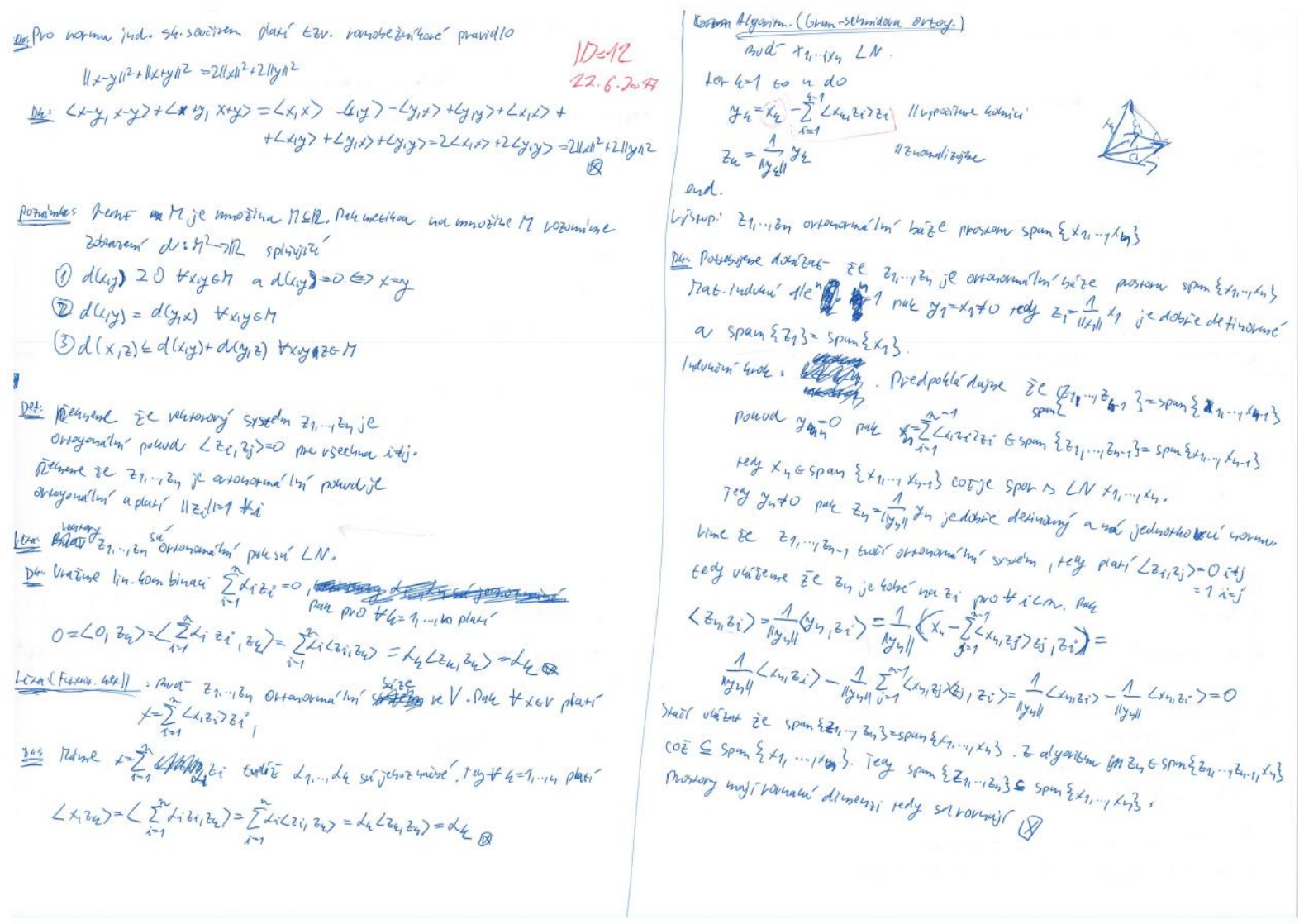

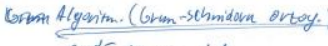

or $\varepsilon_{1} 1$ to $n$ do

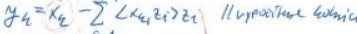

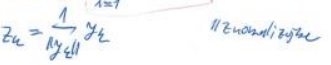

Lip.: Z1,

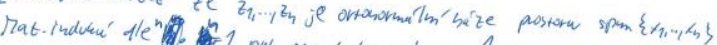

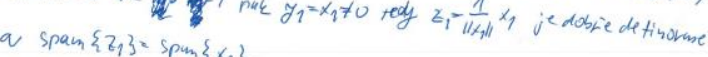

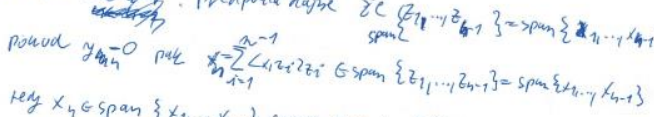
Tey $x_{n} \in$ span $\left\{x_{1, \cdots-1} x_{n-1}\right\}$ cotje spons $L N x_{1}, \cdots, x_{n}$.

hine ze

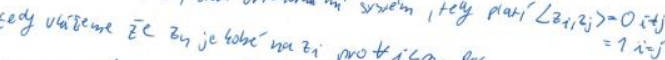

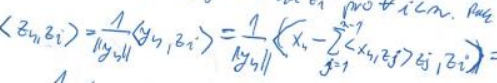

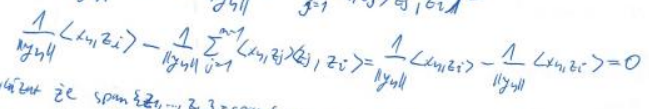

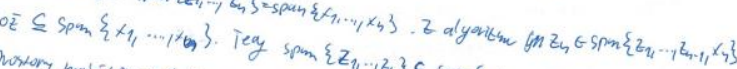

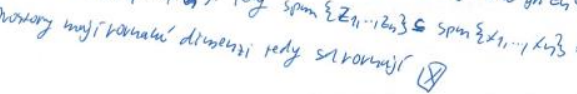

Figure 13: Student example linear form preparation - highly rated-part 4

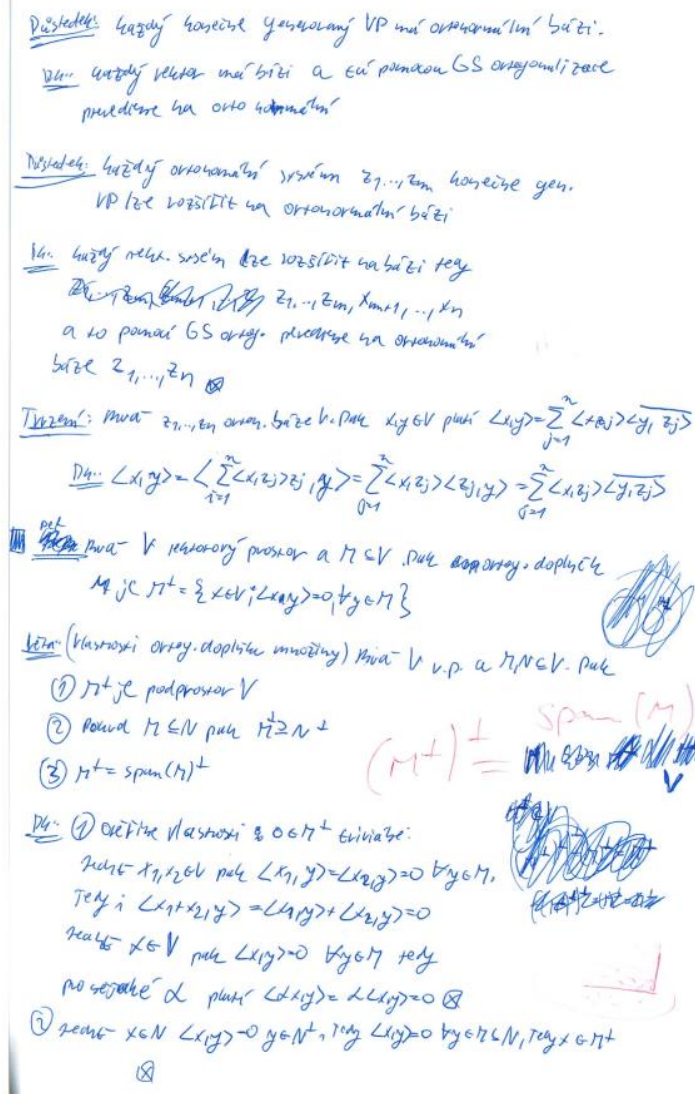


Figure 14: Student example linear form preparation - highly rated-part 5

maxa A: $u \rightarrow v$ je Lin. zahr

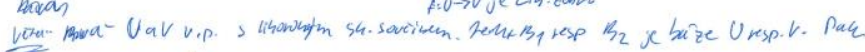
wative $[t]_{k, 1}$ jeorroy poquen $\leftrightarrow$ dhal phat $\langle f(x), H(y)\rangle=\langle x, y\rangle \forall x, y+v$

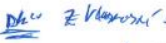

$$
\left.\langle x, y\rangle=[x]_{B_{1}} L_{y}\right]_{B_{1}}
$$

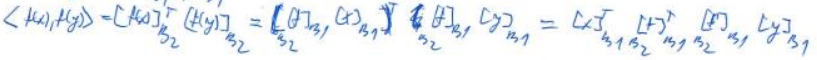

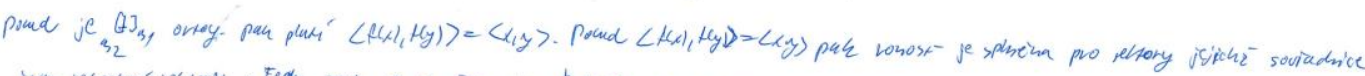

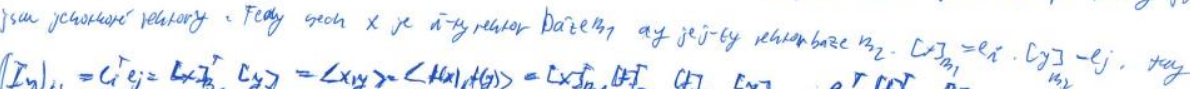

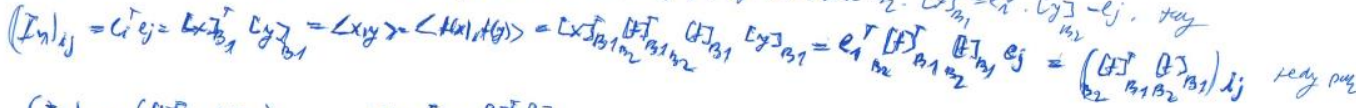

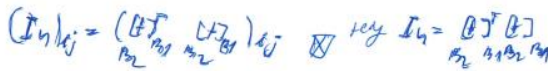

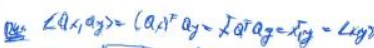

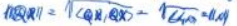

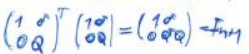




\section{B. Appendix - Questionnaire}

Figure 15: Completed questionnaire example
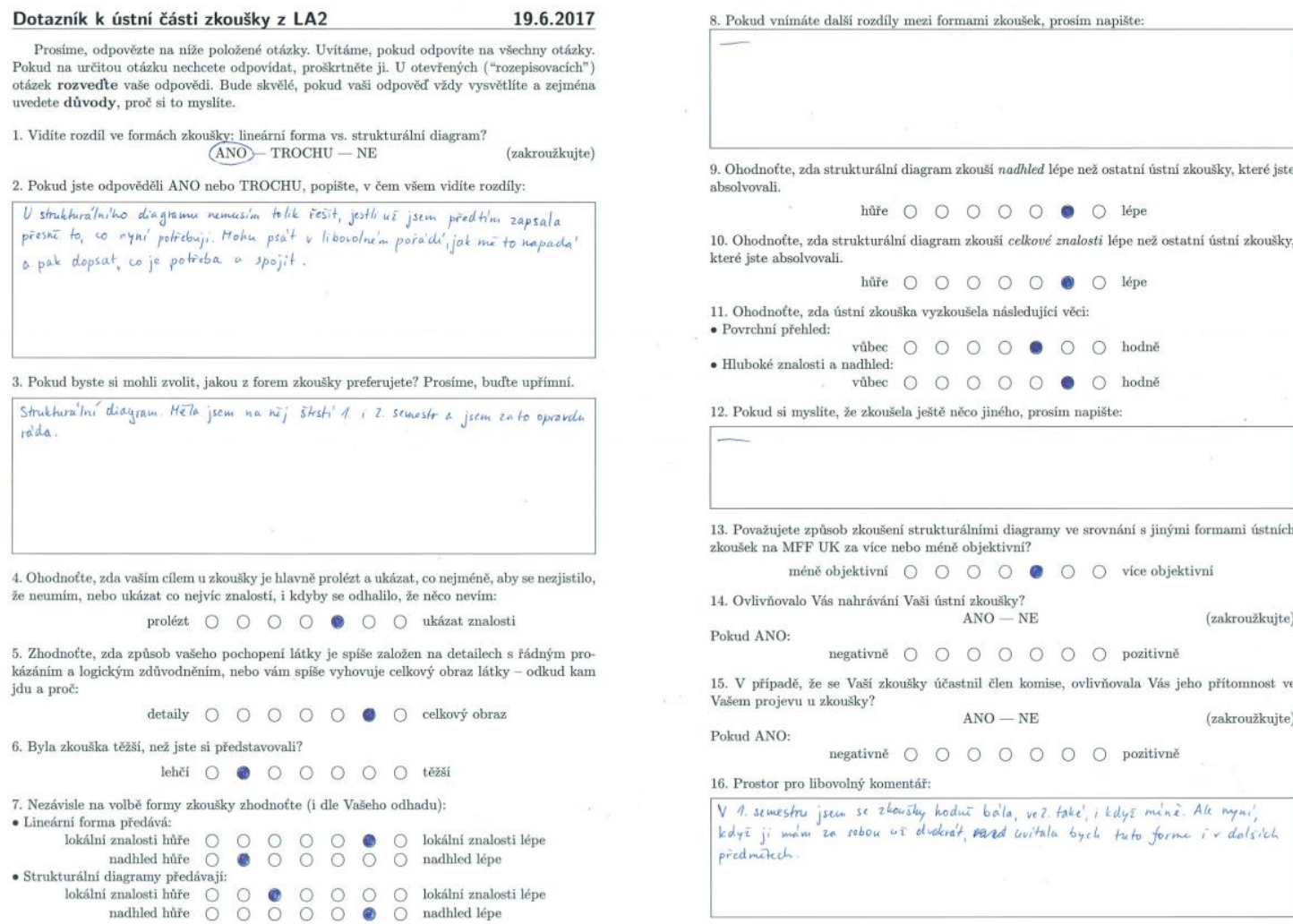

9. Ohodnotte, zda strukturální diagram zkouši nadhled lépe než ostatní ústní zkoušsy, které jste absolvovali. hữe $0 \quad 0 \quad 0 \quad 0 \quad 0 \quad 0 \quad 0$ lépe

10. Ohodnotte, zda strukturální diagram zkouši cellové znalosti lépe než ostatní ústni zkoušky, které jste absolvovali.

hữe $\bigcirc \bigcirc 0 \quad 0 \quad 0 \quad 0$ lépe

11. Ohodnotte, zda ústni zkoušska vyzkoušela následujici vêcił

- Povrchni préthled:

- Hluboké znalosti a vaudblec $:$ :

vunbec $\bigcirc \bigcirc \bigcirc \bigcirc \bigcirc \bullet \bigcirc$ hodně

12. Pokud si myslite, že zkoušela ješté něco jiného, prosim napište:

-

13. Považujete zpưsob zkoušení strukturánímín diagramy ve srovnání $\mathrm{s}$ jinǵmi formami ústníc zkoušek na MFF UK za více nebo méně objektivní? méně objekttivní $\quad 0 \quad 0 \quad 0 \quad 0 \quad 0 \quad 0 \quad 0$ více objektivní

14. Ovlivñovalo Vás nahrávání Vaši ústní zkoušky?
ANO - NE

(zakroužkujte) Pokud ANO: negativně $\bigcirc \bigcirc \bigcirc \bigcirc 00$ pozitivně

15. V prípadě, že se Vaši zkoư̌ky účastnil člen komise, ovlivňovala Vás jeho př̆tomnost ve Vašem projevu u zkoussky?
ANO $-\mathrm{NE}$ negativně $0 \quad 0 \quad 0 \quad 0 \quad 0 \quad 0 \quad 0 \quad$ pozitivně 16. Prostor pro libovolný komentár:

V 1. semestru jsem se zhoushy hodué ba'la, ver take', ikdyz mine. Ale myai',

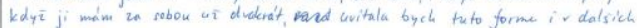
predmitech 
Figure 16: Origin questionnaire - top side

\begin{tabular}{|c|c|c|c|c|l|c|c|c|}
\hline ID & Datum & Forma & Téma & Zkoušejici & Komise & Záznam & Cas př́ipravy & Výsledek \\
\hline & 2.2 .2017 & lineárni strukturálí & & & ANO / NE & & \\
\hline
\end{tabular}

Figure 17: Origin questionnaire - underside

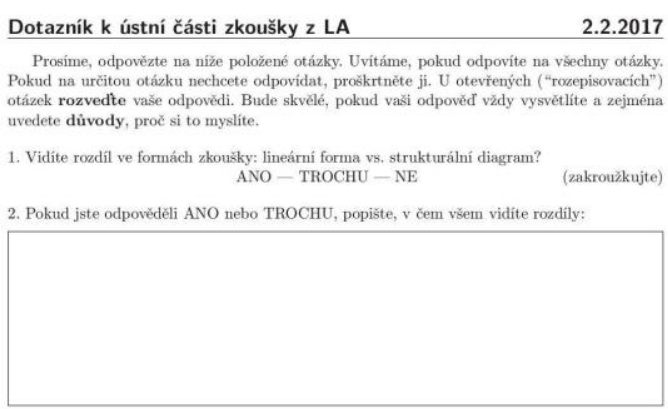

3. Pokud byste si mohli zvolit, jakou z forem zkousky preferujete? Prosime, budte uprímni.

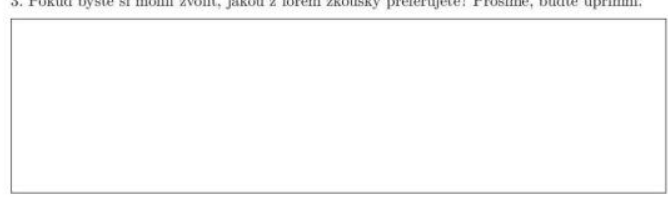

4. Ohodnotte, zda vašim cilem u zkoušky je hlavně proléét a ukázat, co nẹjméně, aby se nezjistilo, Že neumim, nebo ukízat co nejvic znalostí, i kdyby se odhalilo, że nếco nevím: prolézt $\bigcirc \quad 0 \quad 0 \quad 0 \quad 0 \quad 0 \quad 0$ ukízat znalosti

5. Zhodnotte, zda zpủsob vašeho pochopeni látky je spíśe založen na detailech $\mathrm{s}$ rádným prokázáním a logickým zdủvodněním, nebo vám spišse vyhovuje celkový obraz látky - odkud kan jdu a proč:

$$
\text { detaily } 0 \quad 0 \quad 0 \quad 0 \quad 0 \quad 0 \quad 0 \text { celkový obraz }
$$

6. Byla zkouška těžši, než jste si predstavovali?

$$
\text { lehči } 00000000 \text { tẽ̌̆̌si }
$$

7. Nezávisle na volbě formy zkousky zhodnotte (i dle Vašeho odhadu): - Lineairni forma prédávái

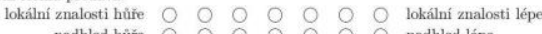
nadhled hứre 00000000 nadhled lépe

- Strukturální diagramy predávaj:

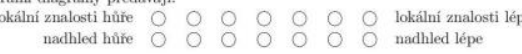

8. Pokud vnímáte dalši rozdily mezi formami zkoušek, prosím napište:

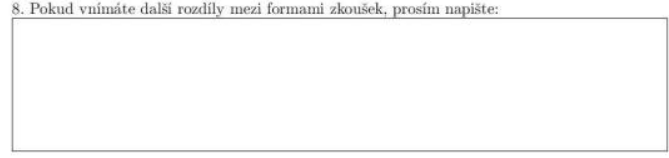

9. Ohodnotte, zda strukturální diagram zkouši nadhled lépe než ostatní ústní zkoušky, které jste absolvovali. hữée 00000000 lépe 10. Ohodnotte, zda strukturální diagram zkouš celkové znalosti lépe než ostatní ústni zkoušky, které jste absolvovali.

hữe $\bigcirc \circ 00000$ lépe

11. Ohodnotte, zda ústni zkoư̌ka vyzkoušela následujicí věci:

- Povrchní prehled:

- Hluboké zanasostia vúbec $\bigcirc \quad 0 \quad 0 \quad 0 \quad 0 \quad 0$ hodnè

vübec $\bigcirc \bigcirc 0 \quad 0 \quad 0$ hodr

12. Pokud si myslite, že zkousela ještè nēco jinêho, prosim napiste:

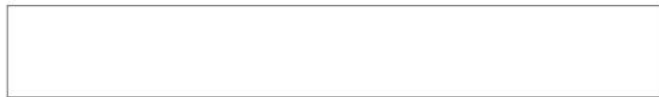

13. Povǎ̌ujete zpúsob zkoušeni strukturálními diagramy ve srovnání s jingimi formami ústnic zkousek na MFF UK za vice nebo méné objektivní

$$
\text { méně objektivni } 0000000 \text { vice objektivní }
$$

14. Ovlivñovalo vás nahrávání Vaasi ústní zkousky?

Pokud ANO:

negativně $\bigcirc \quad 0 \quad 0 \quad 0 \quad 0 \quad 0 \quad 0$ pozitivně

(zakroǔkujte)

15. V phr̉padê, że se vaši zkoušky účastnil člen komise, oxlivñovala vás jeho prítomnost ve vašen projevu u zkousky? ANO $-\mathrm{NE}$ Pokud ANO:

negativně 0000000 pozitivnĕ

16. Prostor pro libovolný komentáí:

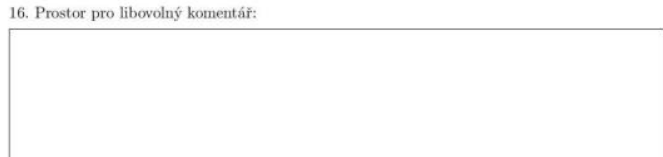

